This article has been scanned by iThenticat No plagiarism detected

Volume 3, Issue 6, December 2021

p. 366-383

\title{
ROLE OF THE BUDGET IN RAISING THE EFFICIENCY OF FINANCIAL PERFORMANCE IN THE DIRECTORATE OF EDUCATION IN THE NORTHERN GOVERNORATES
}

http: //dx.doi.org/10.47832/2757-5403.6-3.26

Wafaa Mohammad ASHOUR ${ }^{1}$ \& Narmeen Ismat ZATARA ${ }^{2}$

\begin{abstract}
:
The study aimed to identify the role of the budget in raising the efficiency of financial performance in the Directorate of Education in the northern governorates. The two researchers used: qualitative research.

The interview tool was adopted: it consisted of (3) main themes. The first axis: about budget preparation and included (8) questions. The second axis: about the implementation of the budget, and included (7) questions. The third axis: about the relationship between the budget and the efficiency of financial performance. The interview questions included open questions and closed questions.

The study population is made up of members of the Finance Committee and is responsible for the budget preparation process. They number (68) in the second semester of the academic year 2020-2021. The sample size is (19) by $28 \%$. The most important results are:

- The budget plays a major role in raising the efficiency of financial performance, as it is one of the activities planning tools, as the revenue amounts are distributed among the budget items.

- The budget has a role in raising the efficiency of financial performance in the education directorates through its oversight role on performance.

Recommendations:

- Increasing the powers of education directorates in the budget preparation process by the Ministry of Education in order to achieve a higher level of flexibility in it to meet the needs within the priorities.

- Conducting training courses on budget preparation, implementation, and follow-up by the Ministry of Education in cooperation with the

\footnotetext{
${ }^{1}$ Researcher, Arab American University, Palestine, Wafa.aashour@hotmail.com, https: //orcid.org/0000-0002$\underline{1823-5938}$

${ }^{\frac{18}{2}}$ Researcher, Arab American University, Palestine, narmeenjafar@hotmail.com, https: //orcid.org/0000-0001$\underline{8062-5534}$
}

Copyright $(\mathcal{C}$ Published by IJHER Journal, www.ijherjournal.com Rimar Academy, Fatih, Istanbul, 34093 Turkey

All rights reserved 
Ministry of Finance, and not to be limited to department heads only, but extend to all employees in the directorate's departments and those willing and qualified to prepare budgets.

Key words: The Budget, The Efficiency of Financial Performance, The Directorate of Education, The Northern Governorates, The Finance Committee.
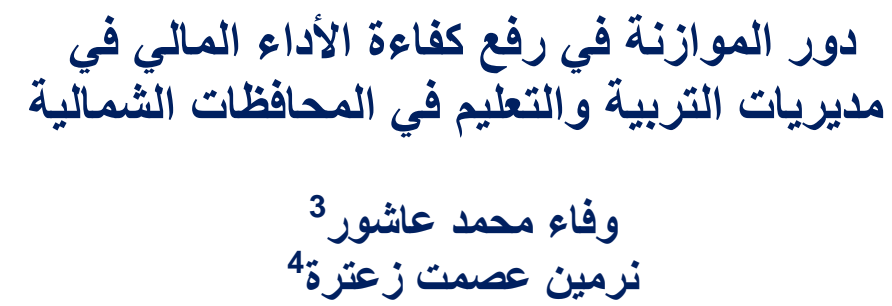

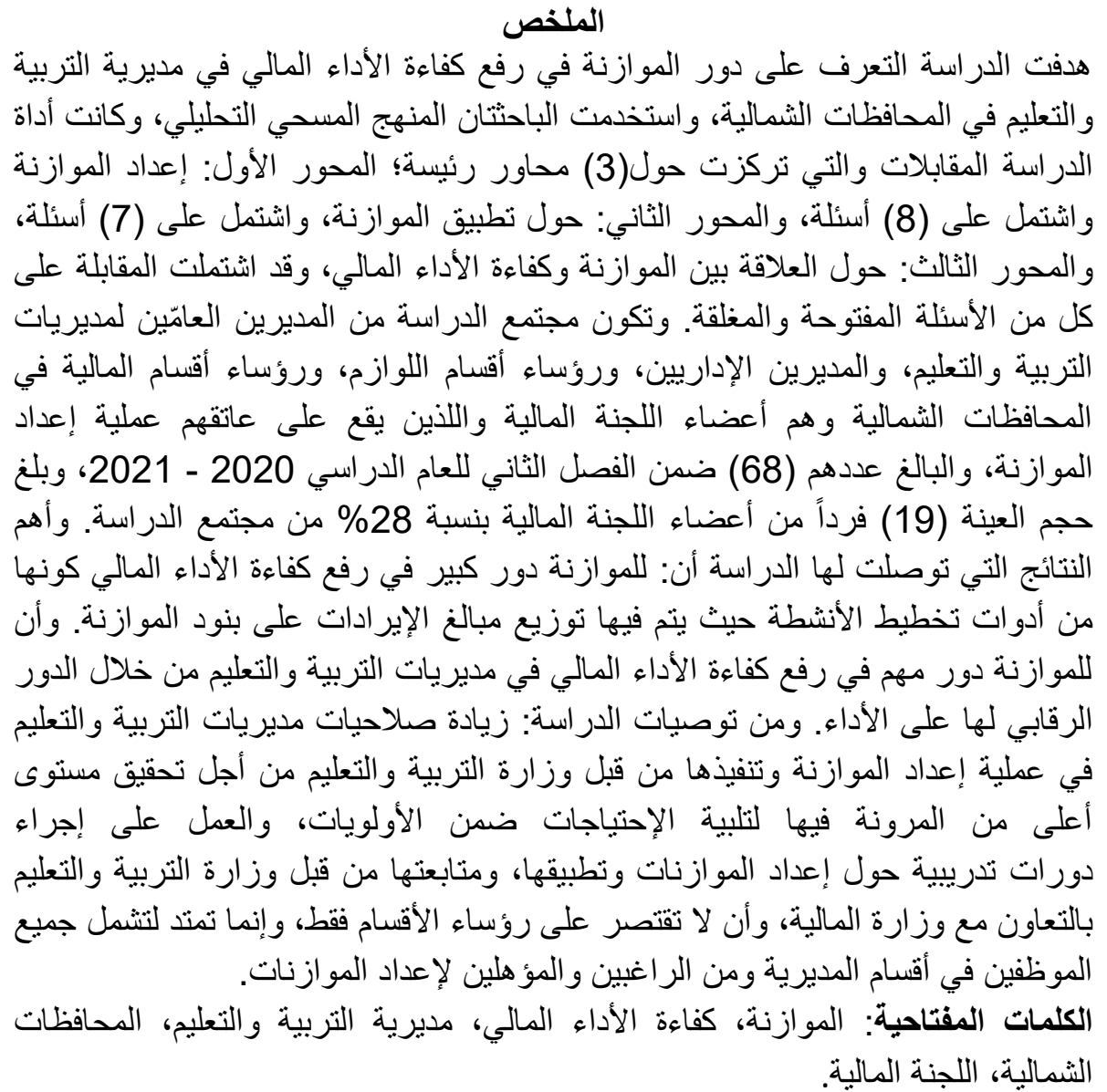

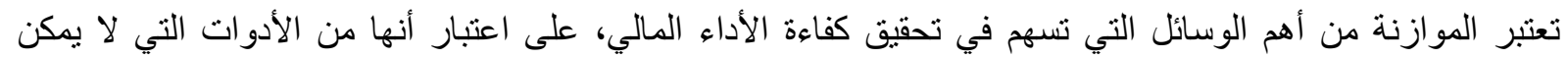

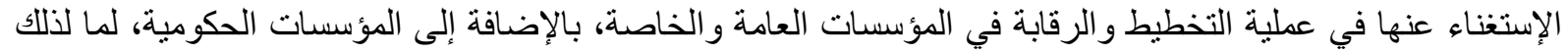

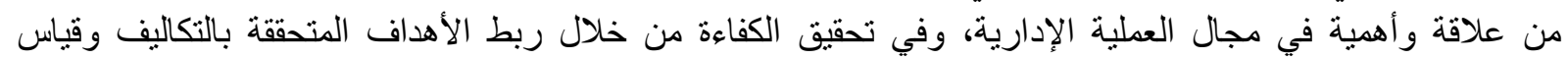

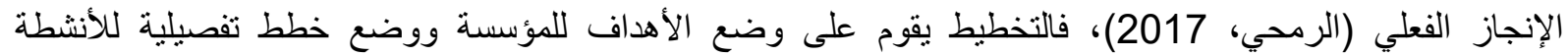


و البرامج التي تخدم تحقيق تلك الأهداف، أما الناحية الرقابية نكون منمثلة في مقارنة بيانات الموازنة المقدرة بالنتائج

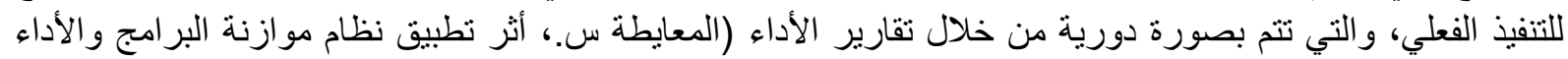

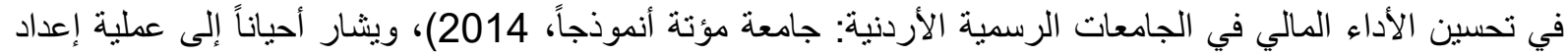
الموازنة التي يتم تثغيلها من خلال السنة المالية الكاملة (Masakala, Omol, Wauyo, \& Okumu, 2017)

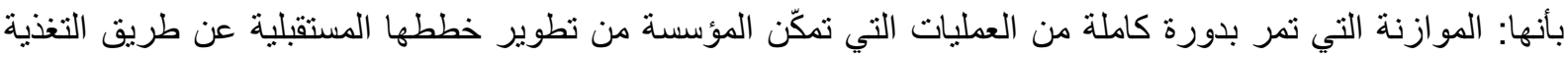

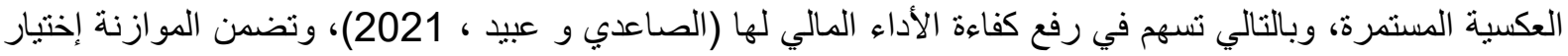

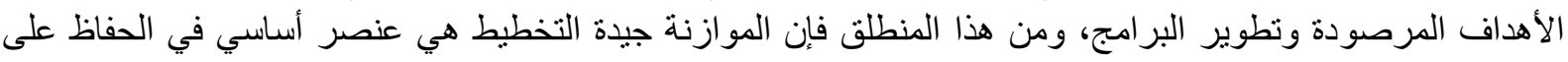

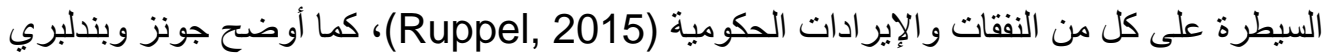

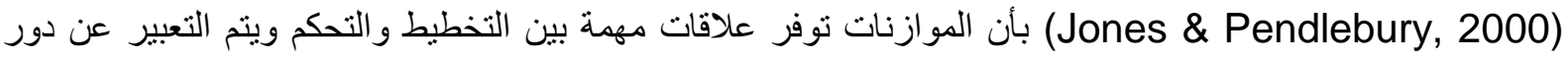

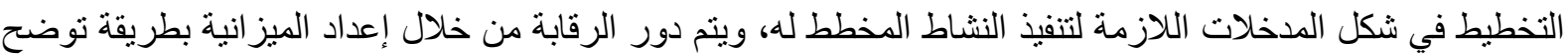
المدخلات و الموارد المخصصة للأقسام أو الإدارات لأداء المهام المسؤولة عنها، كما أنها تعبير عن خطة التهائة التربية بطريقة

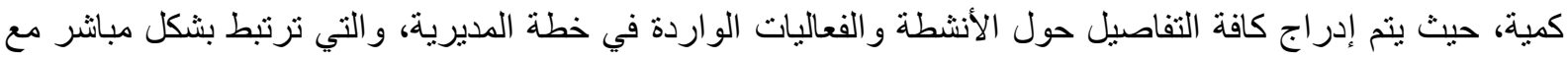

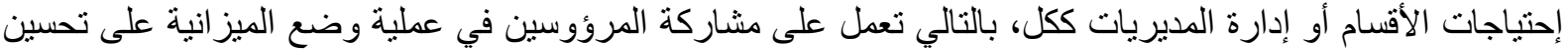

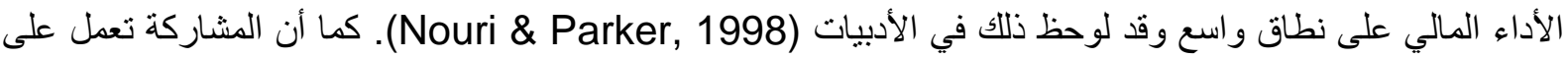
وضع عملية الموازنة كوظيفة من خلال حث المرؤوسين على القبول والإلتزام بأهداف ميزانيتهم، وتعمل على الإنى تبادل

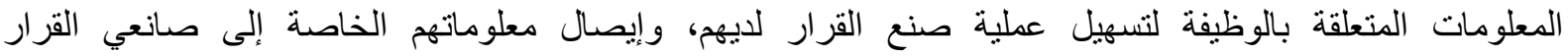

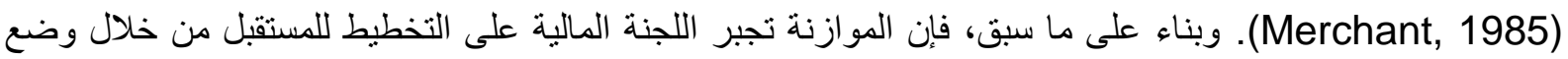

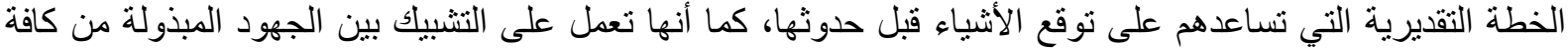

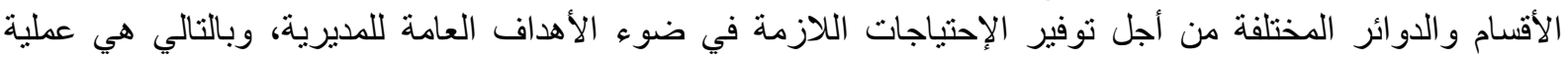

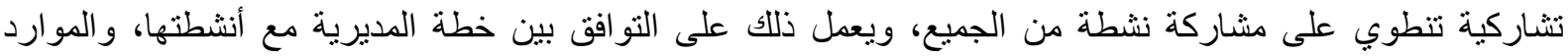

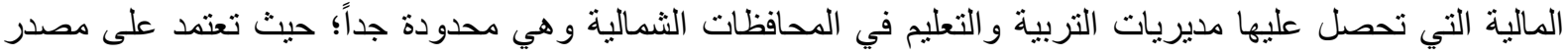

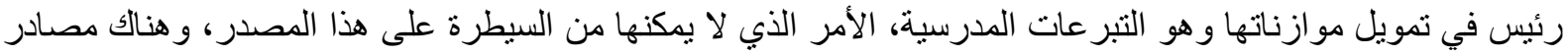

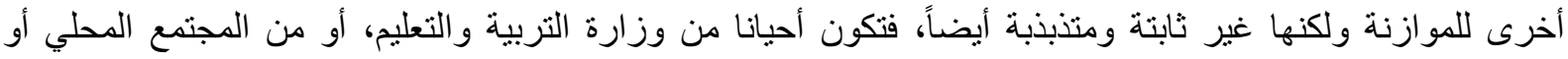

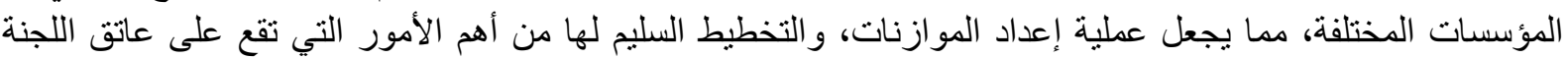

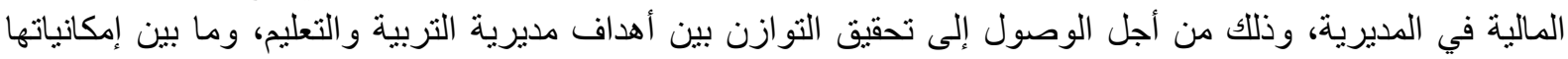

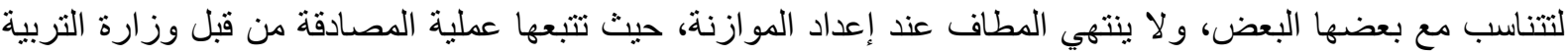

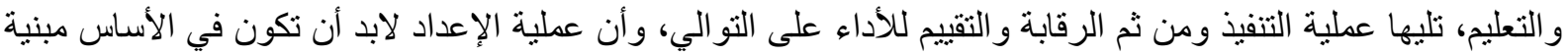

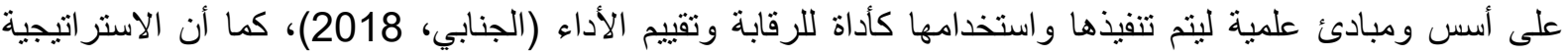

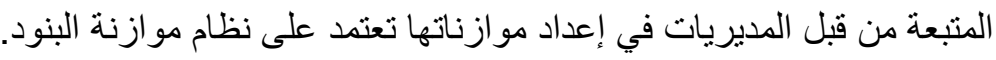

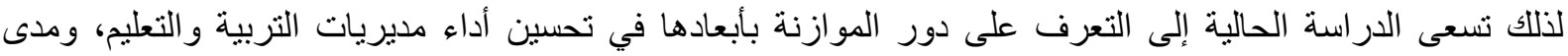

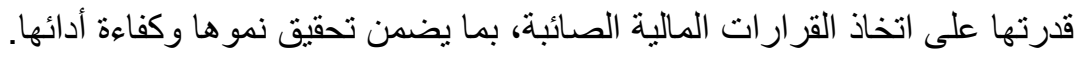

مشكلة الاراسة وأسئلتها:

إن معظم مديريات التربية والتعليم تعاني من قلة الموارد المالية ومحدوديتها، وتحديد نسبة الأموال التي سوف تحصل

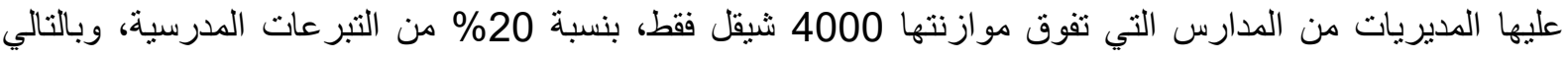

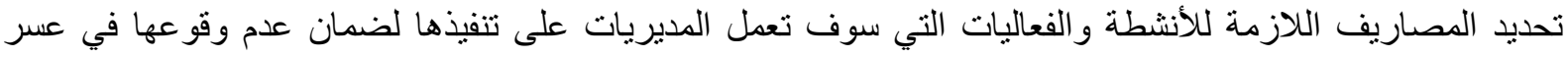

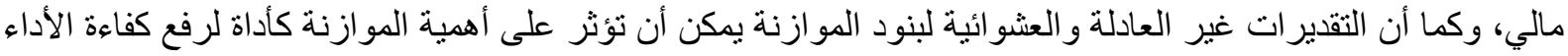

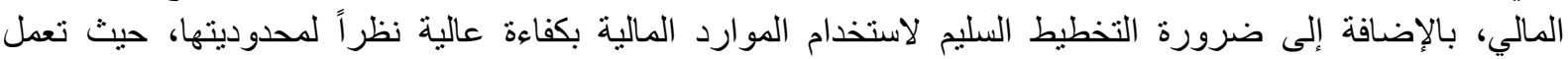

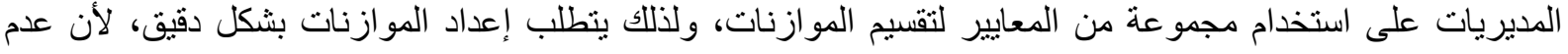

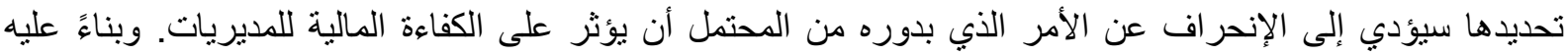
تحدّدت مشكلة الدراسة بالسؤال الرئيس الآتي: "ما دور الموازئنة الإني في رفع كفاءة الأداء المالي في مديريات التربية و التعليم

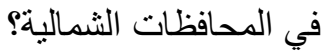


لقد إنبثق عن سؤال الدراسة الرئيس السؤ الين الفر عيين الآتيين:

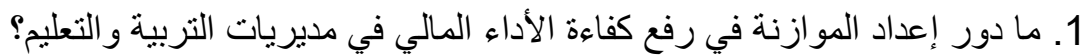

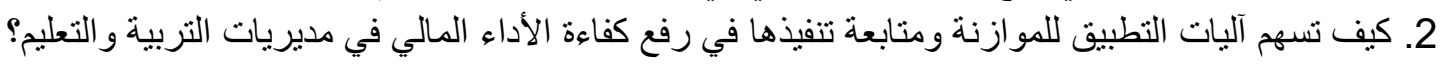

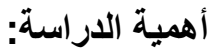

للار اسة أهمية عمليّة تكمن في أنها: 1. قد تكون قاعدة معرفية لدراسات لاحقة ينطلق منها باحثون آخرون، لذا يُّأمل أن تكون بداية في إجراء دراسات 2. قد تفيد متخذي القرار في وزارة التربية والتعليم حول إعتماد معايير إعداد الموازنات في المديريات، واتخاذ القرارات المناسبة في ضو ضوء النتائج. 3. قد تسهم النتائج وتوصيات هذه الدراسة في تطوير أداء اللجنة المالية في مديرية التربية والتعليم، كإمتداد للجهود المبذولة في هذا المجال.

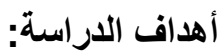
1. محاولة التعرف على الو اقع العملي لاستخدام الموازنة التخطبطية في رفع كفاءة الأداء المالي.

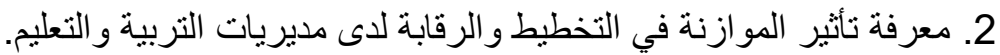

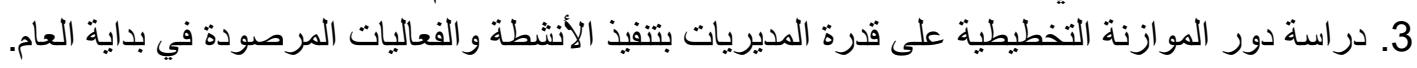

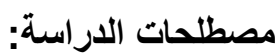

الموازنة: هي تعبير رقمي عن خطط وبر امج الإدارة وتشمل كل العمليات، بما فيها من نتائج منوقعة خلال فترة محددة في المستقبل، وتحتوي في طياتها كل الوحدات بما فيها من قرار الادات مستقبلية للمنشأة (النافعابي، 2016). كفاءة الأداء المالي: هو الأداء الذي يوضح مدى مساهمة الأنشطة في إيجاد القيمة والفاعلية في إستخدام الموارد المالية

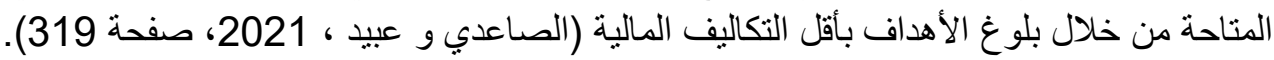

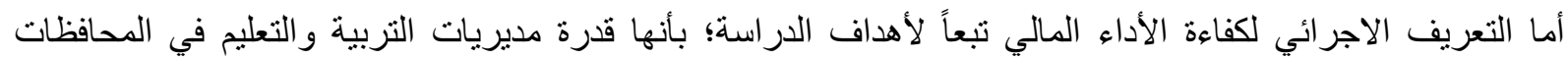

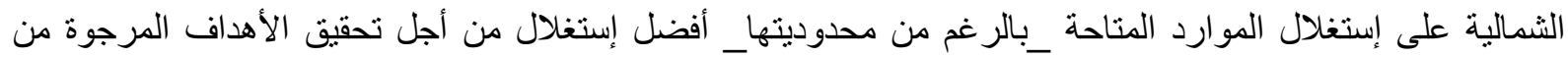

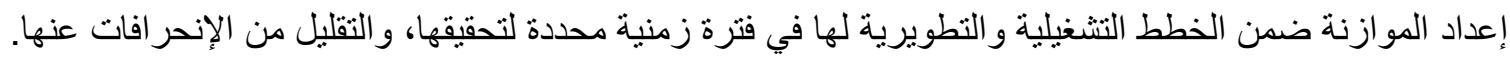

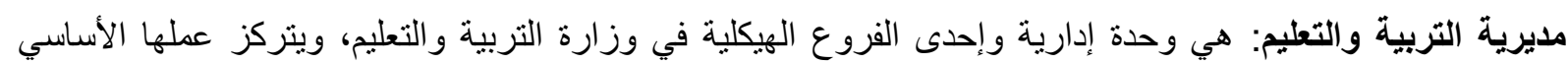

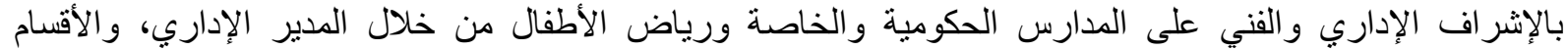

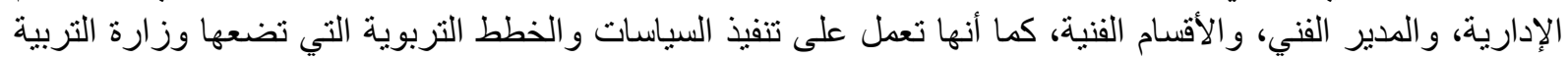

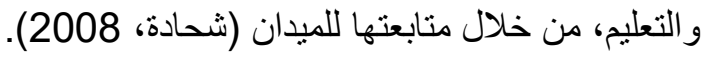
التعريف الإجرائي للمحافظات الثمالية: نطلق على الجزء الثمالي من فلسطين وتشمل المحافظات الآتية: جنين،

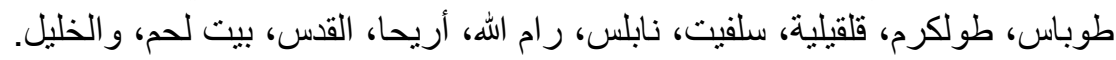
التعريف الإجرائي للجنة المالية: نم تعريفه حسب أغر اض الدراسة بأنهم مجموعة الأفراد المسؤولون عن إعداد وتنفيذ

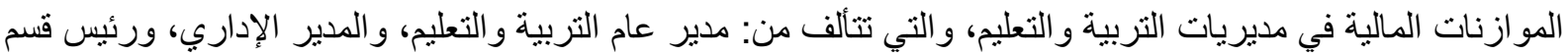

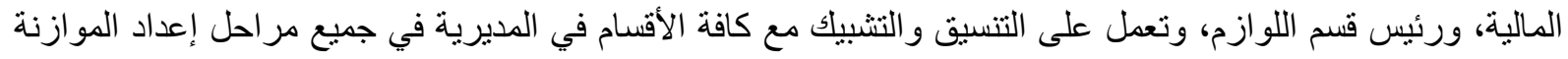


1. الحدود الموضوعية: اقتصرت الدراسة على معرفة دور الموازنة التخطيطية في رفع كفاءة الأداء المالي في مديريات التربية والتعليم في المحافظات الثمالية.

2. الحدود المؤسسية: اقتصرت هذه الدراسة على مديريات التربية و التعليم التابعة لوزارة التربية و التعليم في المحافظات الشمالية. 3. الدود البشرية: اقتصرت الدر اسة على مدير عام التربية والتعليم، والمدير الإداري، ورئيس قسم المالية، ورئيس قسم

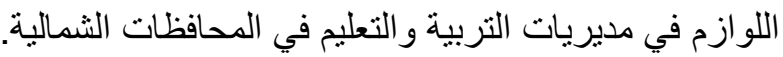

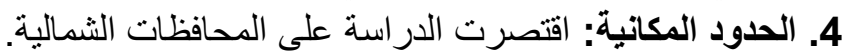

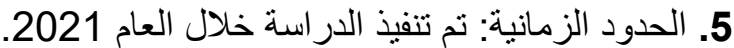

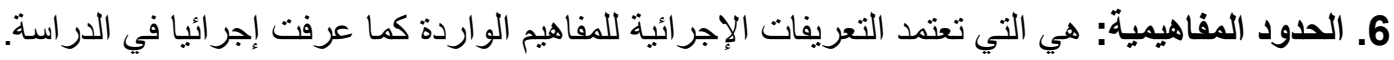
7. الحدود الإجرائية: هي تللك التي تحددت بطبيعة الأدوات المستخدمة في الدراسة، والأساليب الإحصائية المستخدمة، وسمات المجتمع، و العينة، ودرجة الإجئ تعميم النتائج.

الإطار المفاهيمي والدراسات السابقة: يتناول هذا الجزء من الدراسة الإطار المفاهيمي لكل من الموازنة وكفاءة الأداء المالي ضمن محاور الدراسة التي تم إعتمادها وهي كالآتي: أولاً: الموازنة

إن مصطلح الموازنة جاء من كلمة توازن بين ما يتم الإنفاق عليه وبين ما يمكن الحصول عليه من موارد

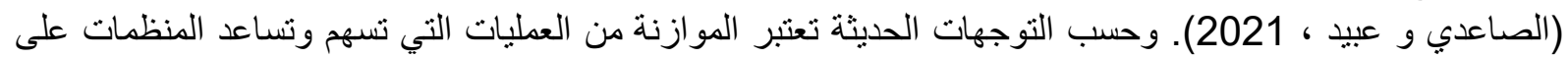

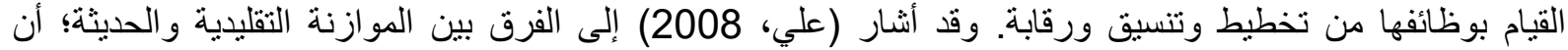

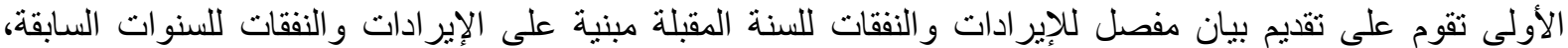

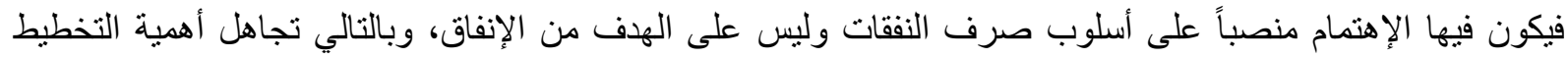

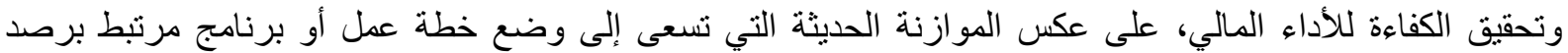

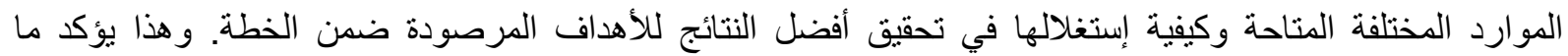
خلصت إليه دراسة (المعايطة س.، أثر نطبيق نظام موازنة البرامج والأداء في تحسين الأداء المالي في الجامعات

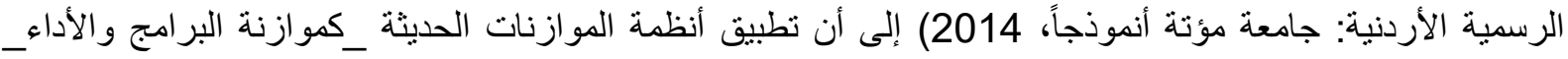

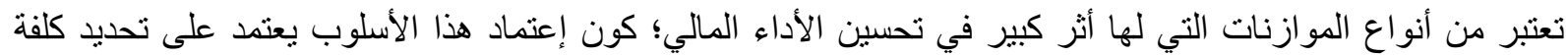

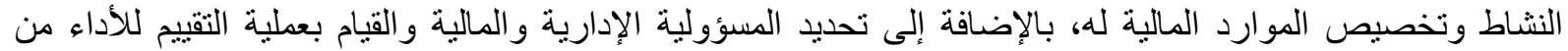

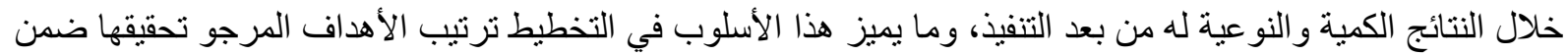
الأولويات، كما يعتبر أسلوب فعّال في ترشيد عملية الإنفاق من خلال الدراسة المعمقة للموارد المتاحة وسبل إنفاقها،

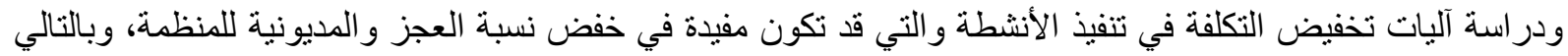
ينعكس إيجاباً على كفاءة الأداء المالي. و عند الحديث عن موازنة "تقديرية" يمكن وصفها بأنها موازنة تقوم على علم المستقبل من خلال التنبؤ أو التبصر بما

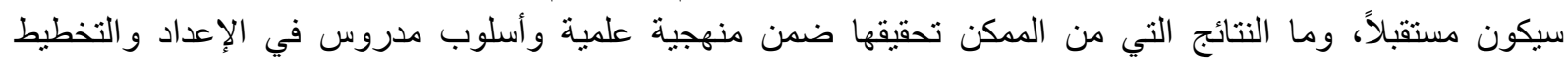

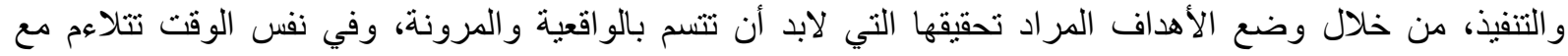

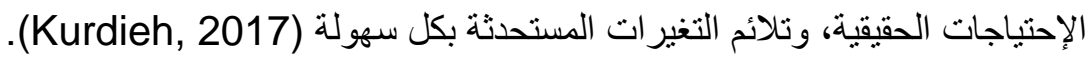

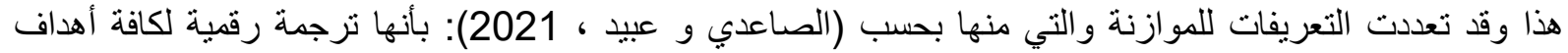

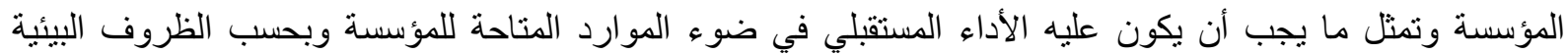
المحيطة ومن خلال آليات محددة في التنفيذ و المتابعة ومن ثم تقييم الأداء الماء المالي لها. 


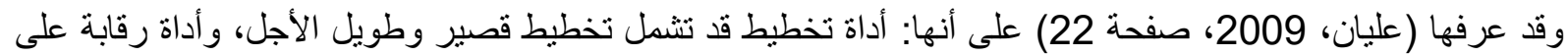

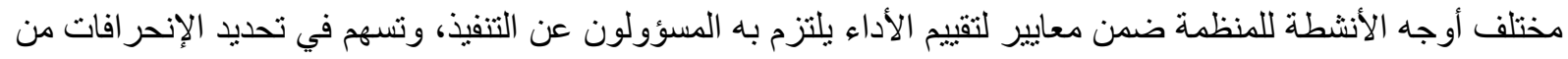

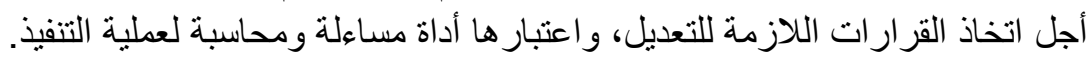

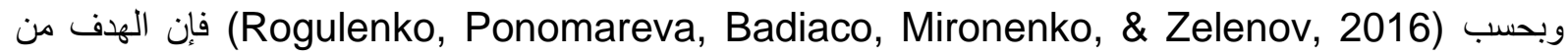
تطوير وتنفيذ نظام الموازنة هو إنشاء أداة للتنظيم الفعّال لإدارة نشاط المؤسسة ووحداتها الهيكلية من خلال التخطيط و التحكم في الدخل والمصروفات وتحليل المؤشرات المالية. وتقوم الموازنة التخطيطية على عدة التهات مراحل في إعدادها

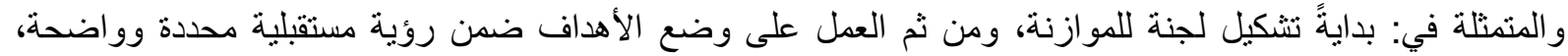

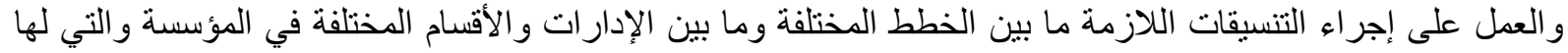

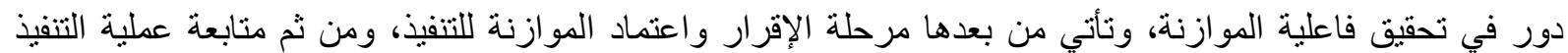

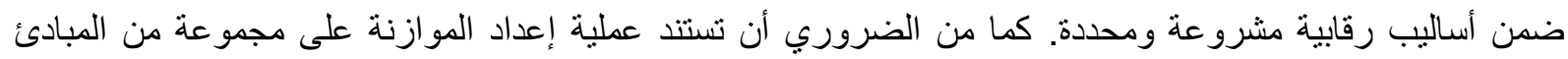
الأساسية، وهي بحسب (كرم، 2018) كالآتي:

• الثمول، ويكون لكافة الإدارات والأقسام و المشاريع ذات الصلة المباثرة بأعمال المؤسسة أو المنظمة.

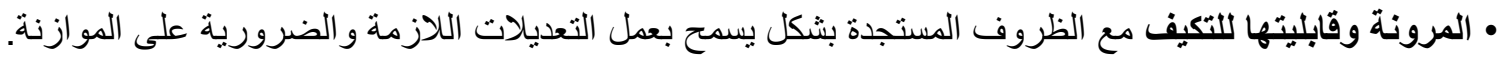

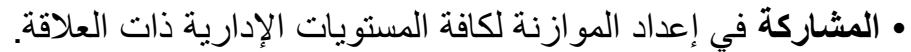

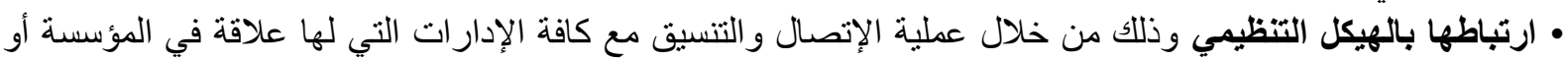
المنظمة.

• اعتماد فترات رقابية زمنية قصيرة خلال السنة المالية لضمان المتابعة المستمرة خلالها.

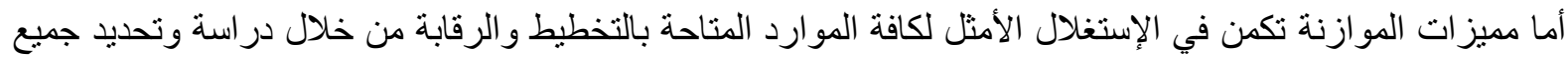

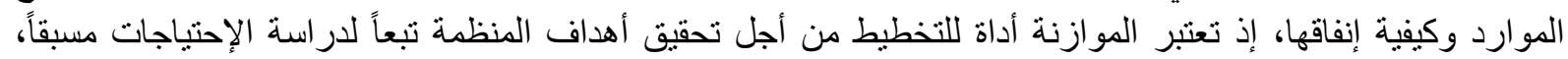

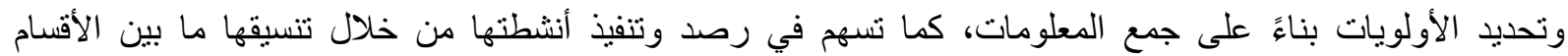
و الإدار ات المختلفة في المنظمة (عليان، 2009)، وتعتبر كأداة رقابية لجميع الأنشطة التي تم تنفيذها من قبل المسؤولين

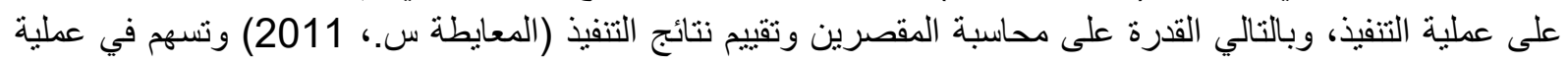
قياس كفاءة الأداء المالي في المنظمة من خلال مقارنة النتائج المحققة بتلك المرجو تحقيقها في الموازنة،؛ فبالتالي تساعد

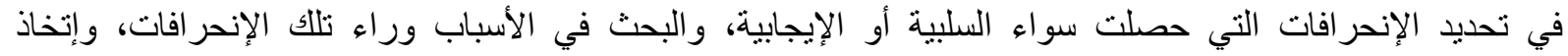

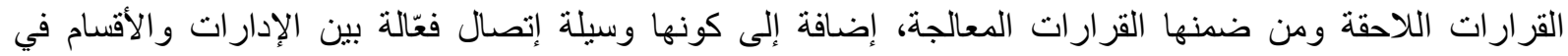

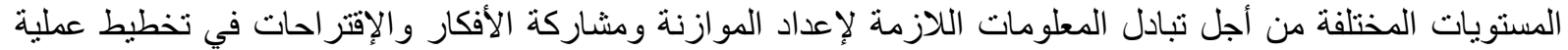

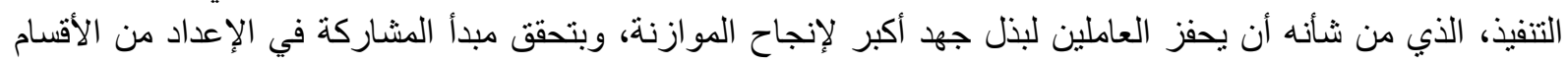

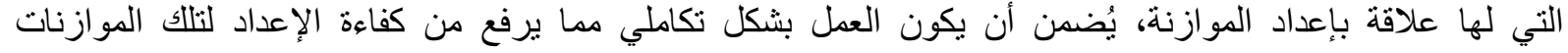

(المومني، 2017).

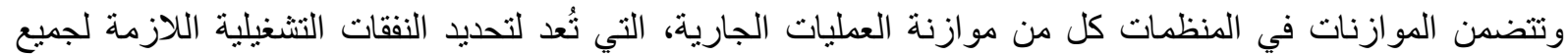
الأنشطة المقررة ضمن الخطة من أجل تنفيذها في السنوات القادمة، وكذللك الموازنة للعمليات الاستتمارية، التي تعتبر

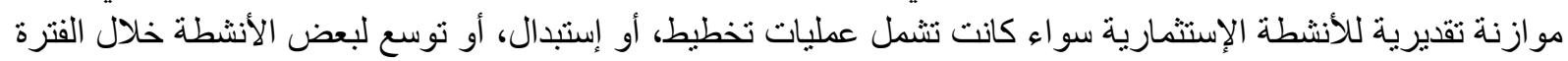
المقبلة، و التي تتطلب أيضاً دراسة لكيفية تقييم بدائل الإستثمار واختبار ها وكيفية تمويلها، بهدف تحقيق أفضل إستخدام

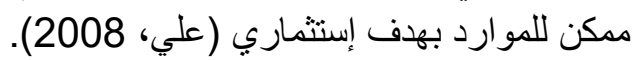

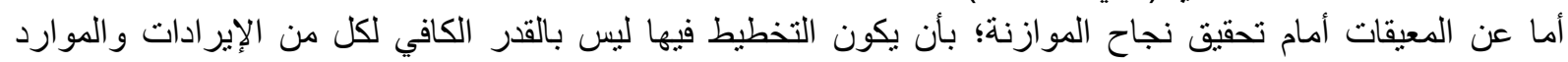

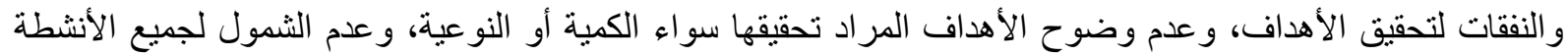

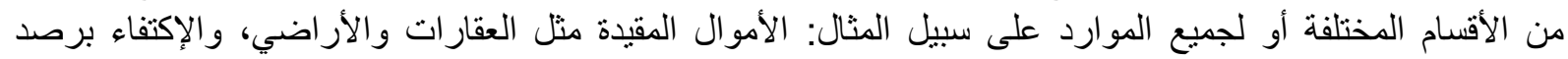

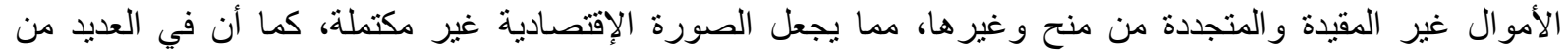

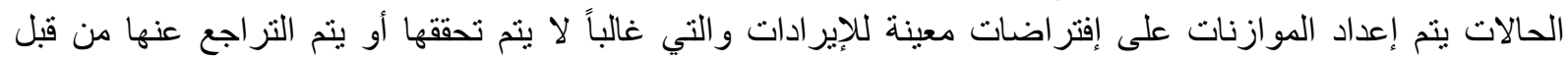

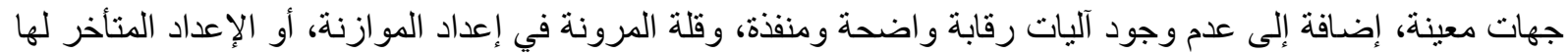

(كرم، 2018) 
يقصد بمصطلح الكفاءة أنه: تحقيق الأهداف بأقل تكلفة ممكنة، ولكن إستخدام هذا المصطلح قد نجده مرنبطاً كثيراً

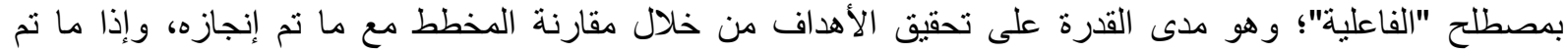

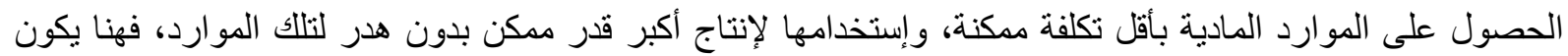

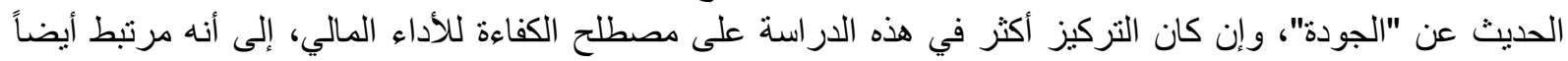
بكل من الفاعلية والجودة التي باتت هدف معظم المنظمات للوصول التركئ إليها (خديجة، 2015).

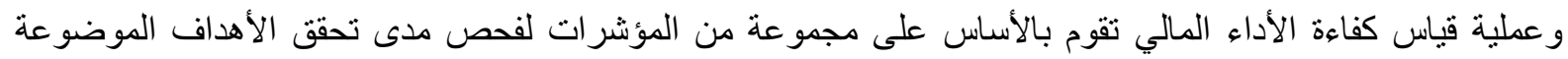

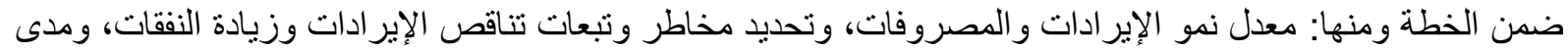

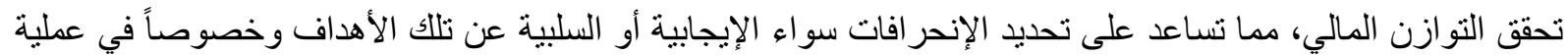

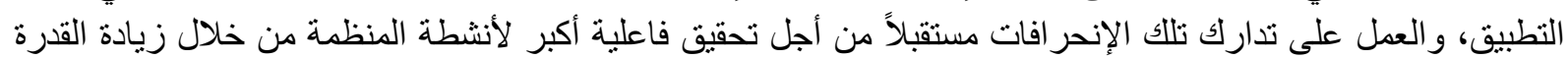

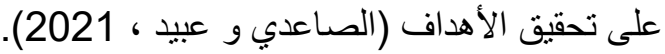

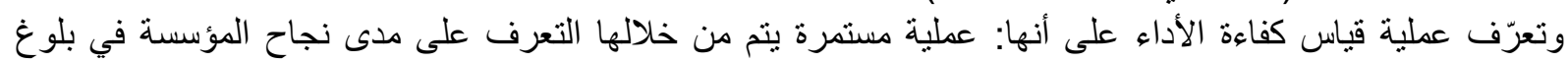

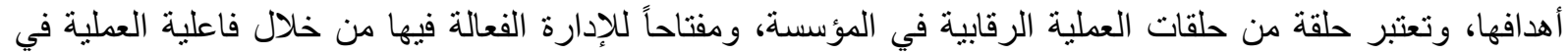

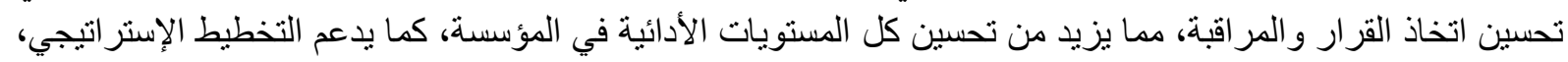

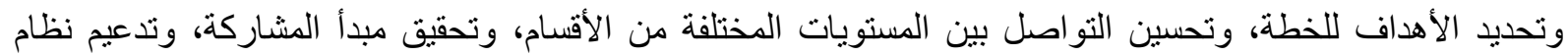
المحاسبة و المسؤولية للعاملين، عملية قياس النتائج و المدخلات ضدن معايير محددة ومقبولة التئل (خديجة، 2015).

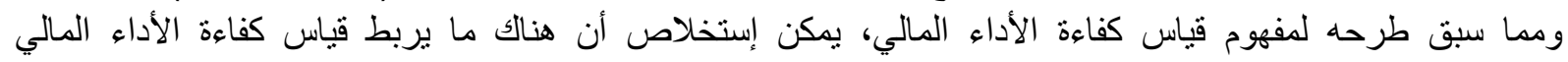

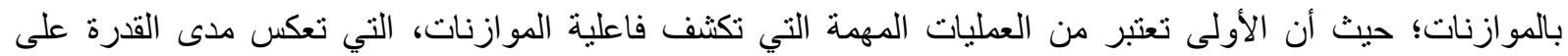

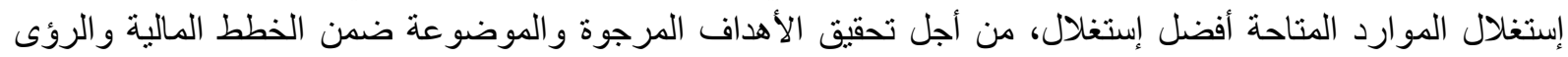

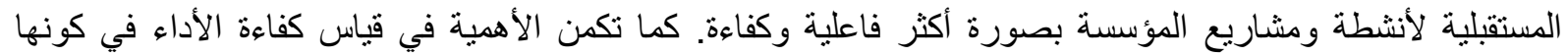

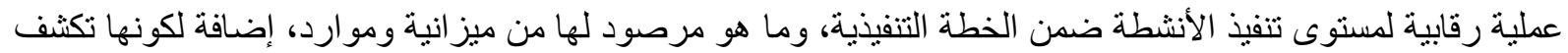

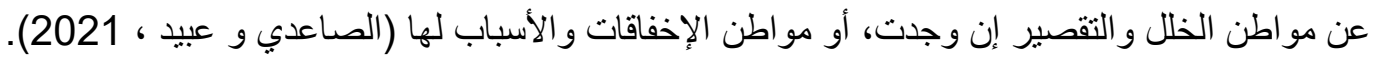

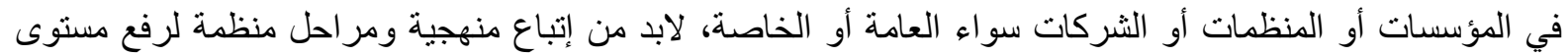

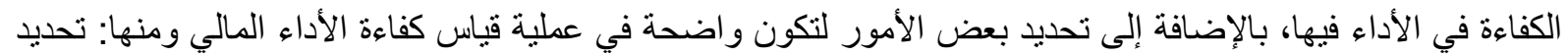

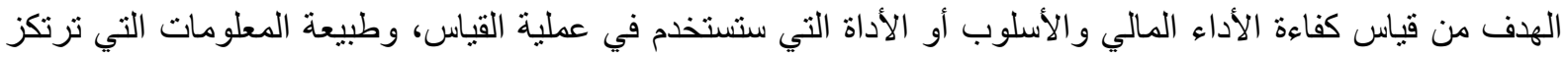

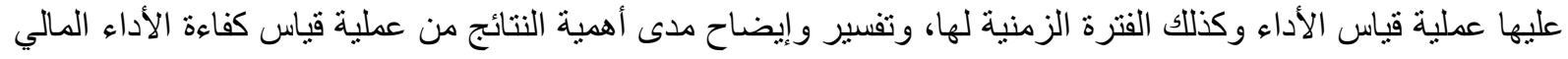

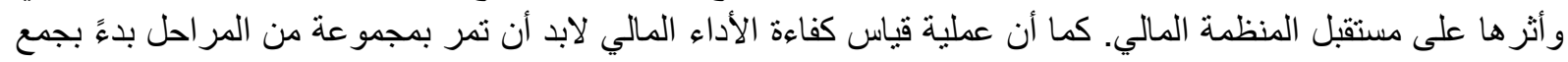
البيانات وتحليلها، ثم وضع نسب لها بهدف تقييمها، والعمل على تحديد مستوى الإنحر اف تجاهاه، ومتابعة العمليات

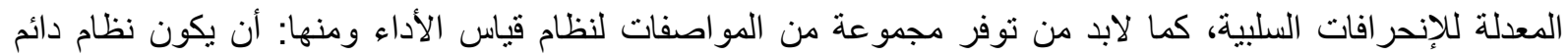

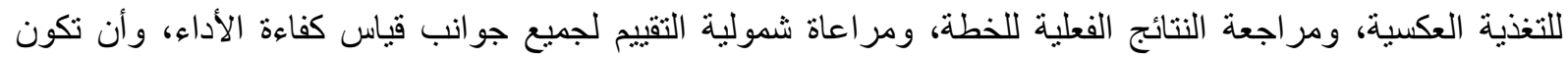
مؤشر ات نظام قياس كفاءة الأداء واضحة وبسيطة، وقابلة للفهم، ومعقولة وقابلة للتحقيق (ابر اهيم، 2014).

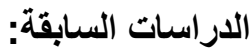

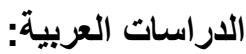

هدفت در اسة (الصاعدي و عبيد ، 2021) إلى كثف دور الموازنة التخطيطية في رفع كفاءة الأداء المالي في شركات

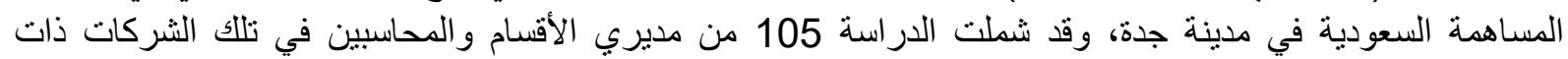

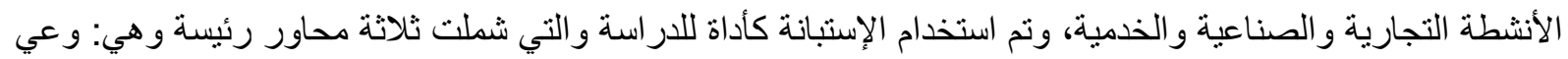

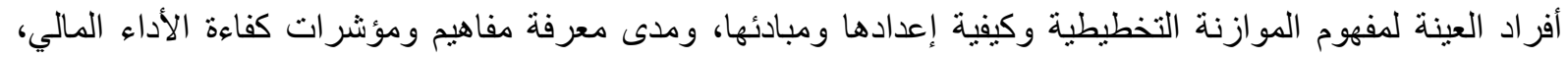

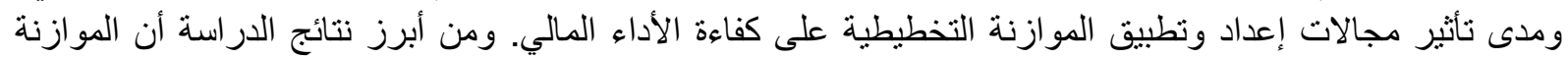

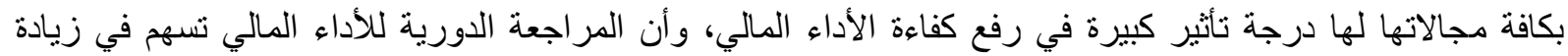
الرقابة على أنشطة المنظمة وبالتالي تزيد من فعالية الثركة فئه 
كما هدفت دراسة (رحاحلة و النسور ، 2019) إلى كثف أثر عوامل النجاح للموازنات التخطيطية في تحسين الأداء

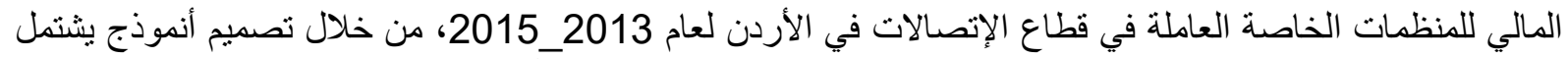

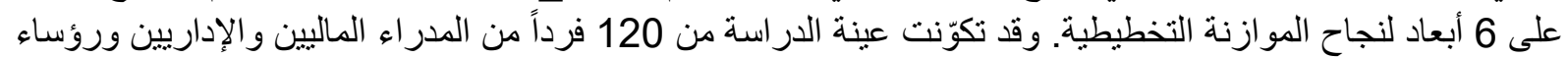

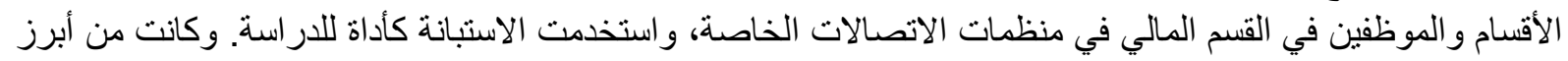

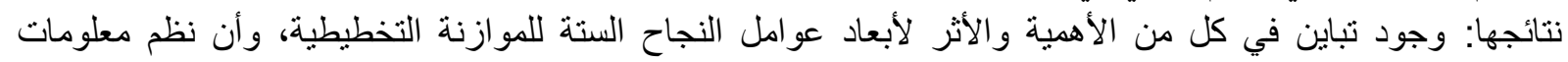

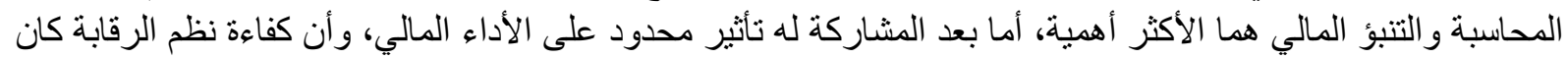

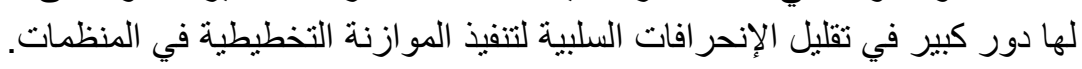

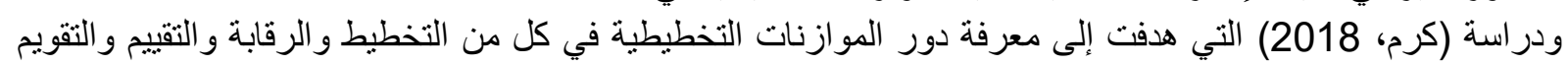

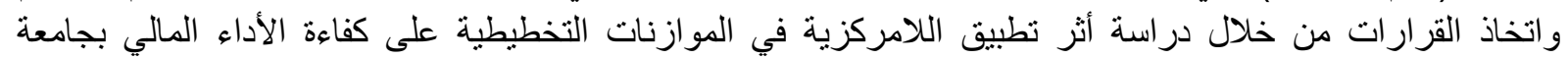

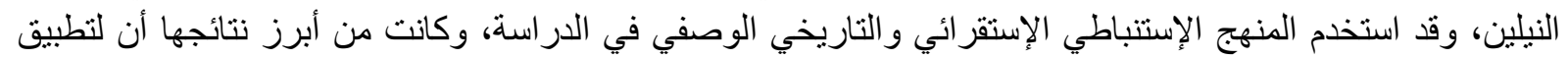

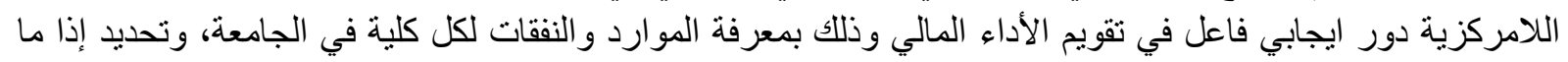

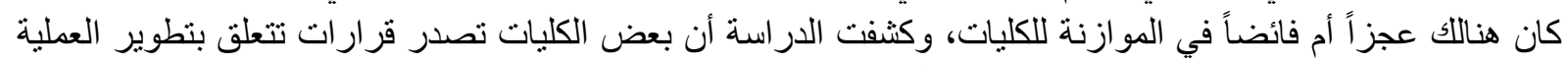

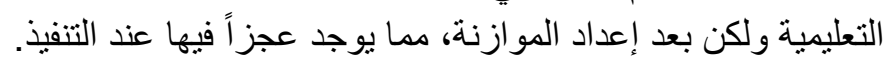

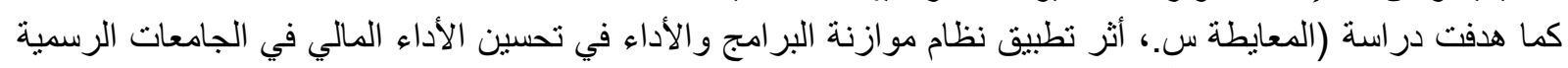

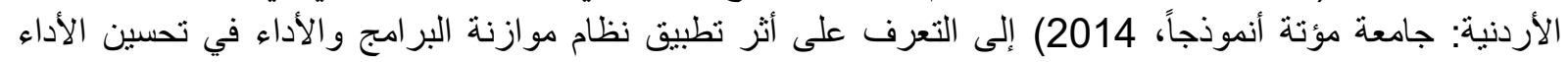

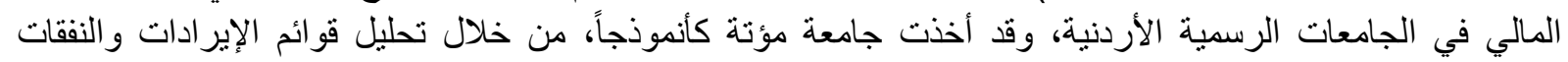

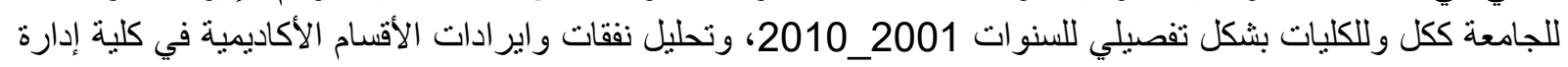

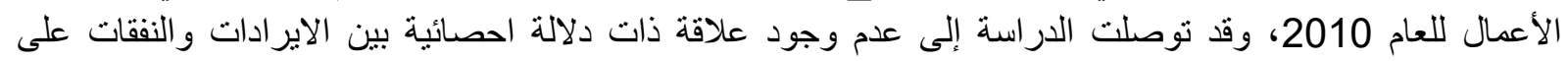

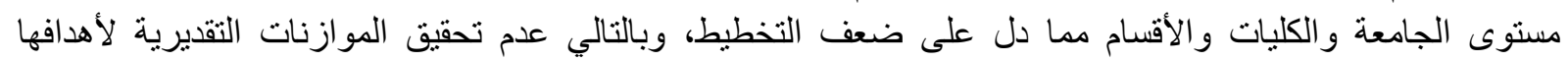
التخطبطية و الرقابية.

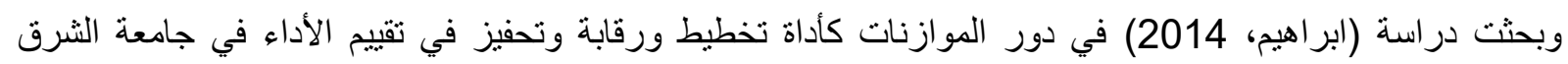

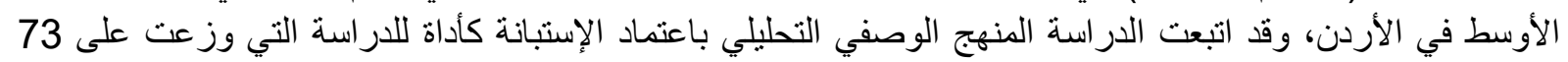

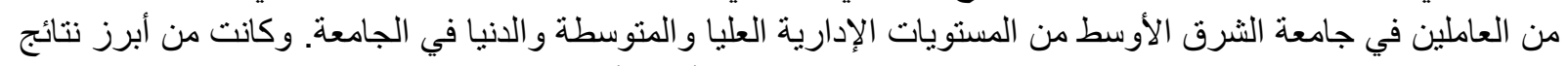

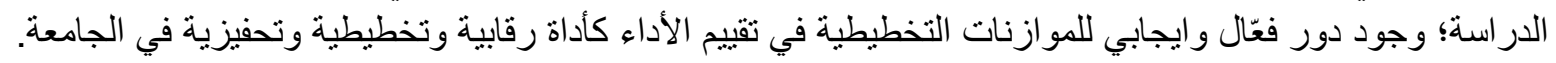

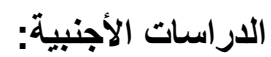

دراسة (Jalali, Mashayekhi , \& Gal, 2019) بحثت في سبب فنل تنفيذ الموازنة القائمة على الأداء في الجامعة

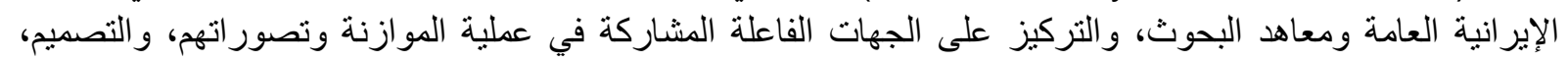

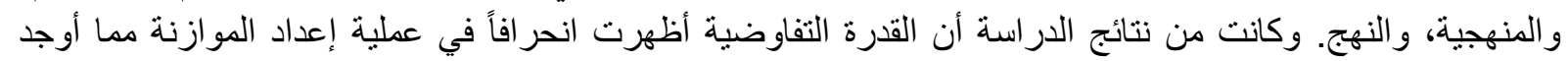

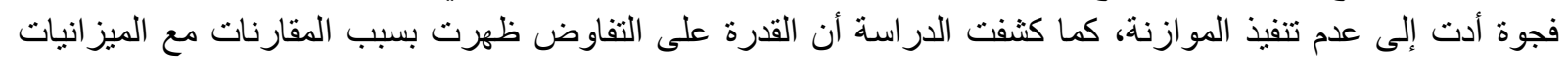

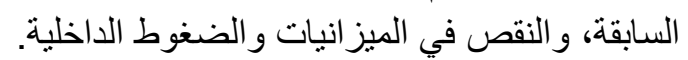
ودراسة (Siregar \& Susanti, 2019) التي هدفت إلى تحديد محددات أخطاء التنبؤ بالميزانية واستكثاف تأثير

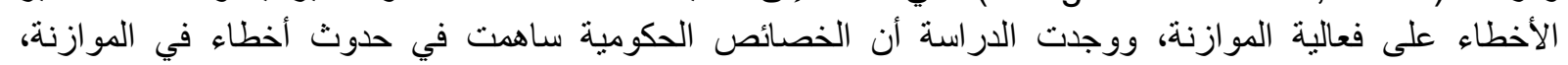

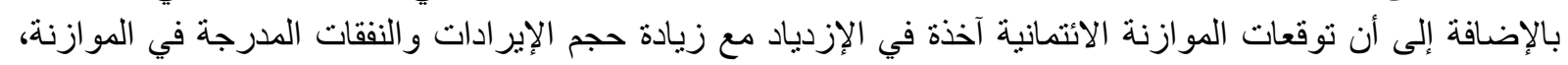

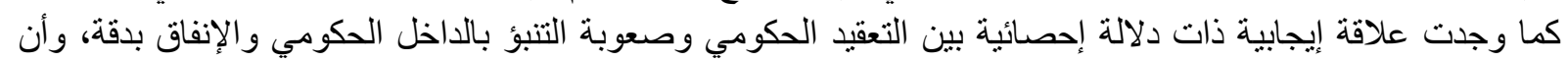

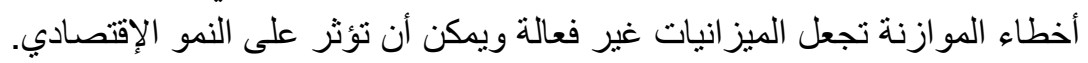

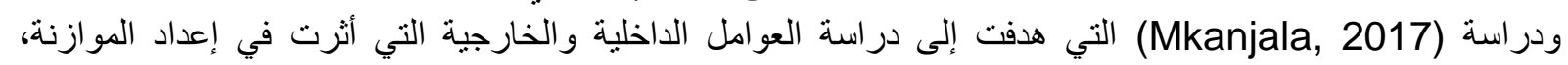

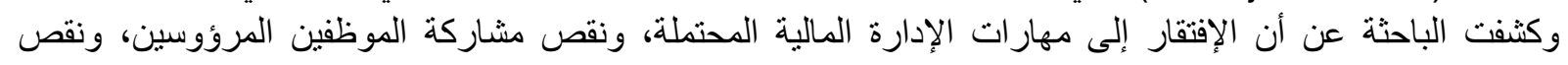

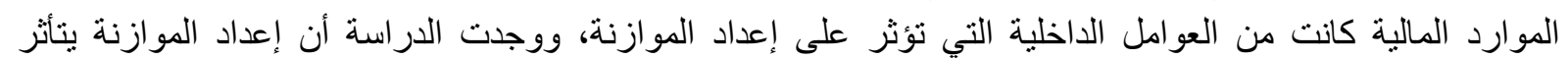

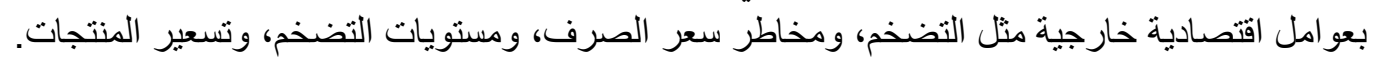

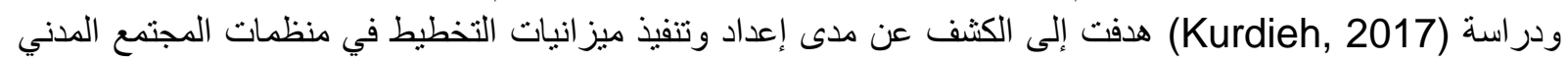

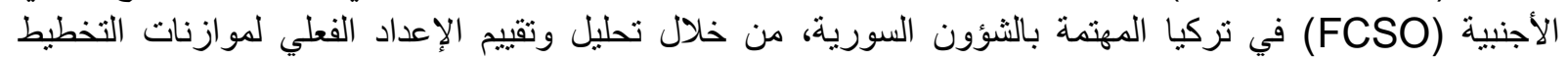

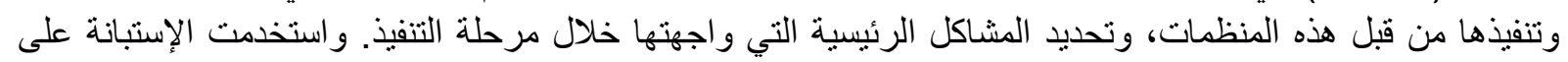




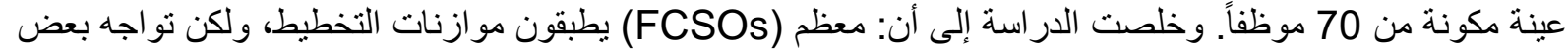

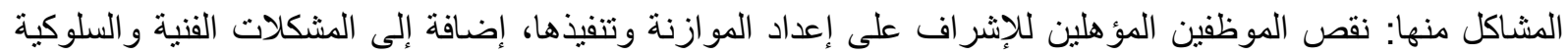

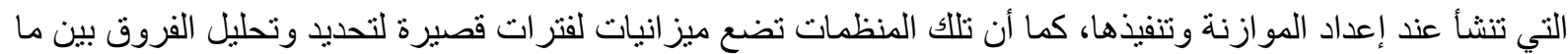

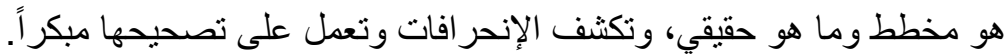

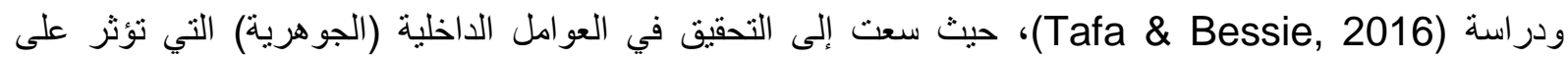

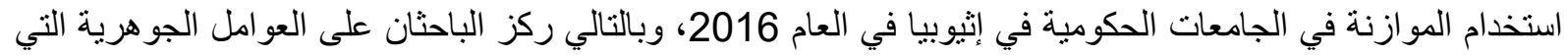

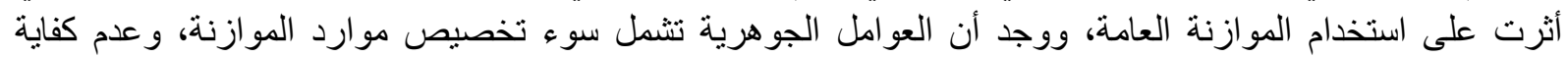

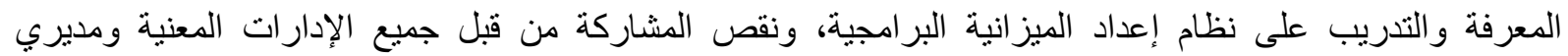

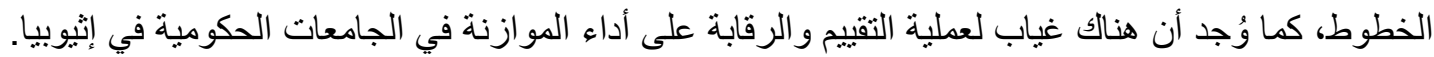

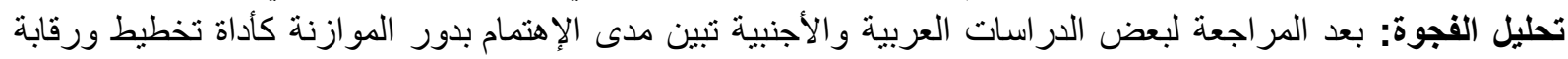

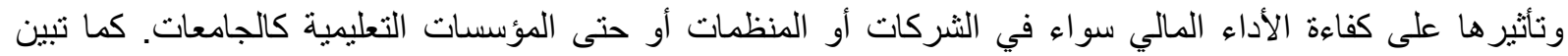

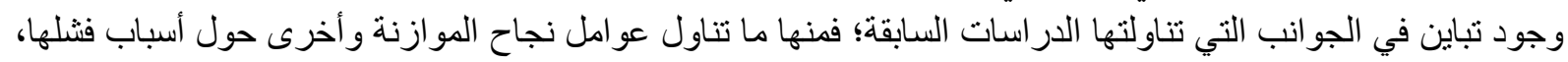

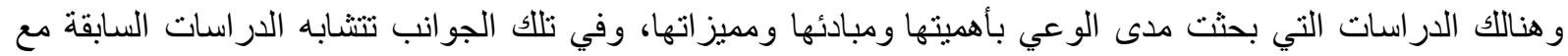

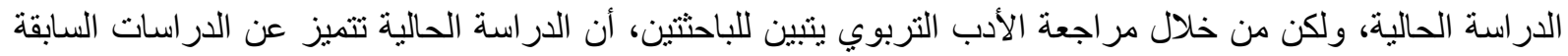

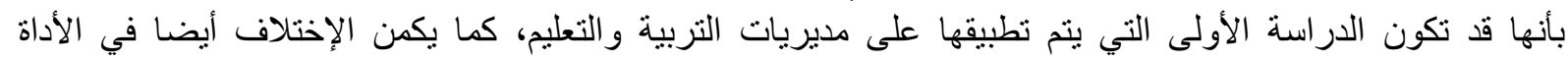
المستخدمة في الدراسة الحالية و هي المقابلات، إضافة إلى الإختلاف في حدودها المكانية المتمثلة في المحافظات الثمالية الإلية

من "الضفة الغربية" في فلسطين.

إجراعات الاراسة

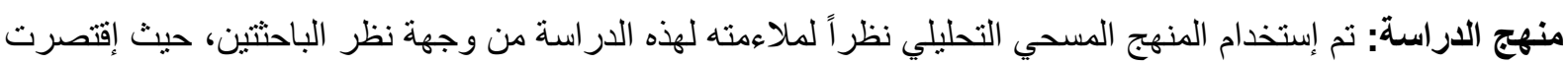

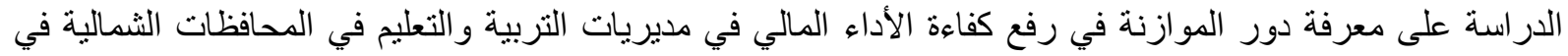

فلسطين.

مجتمع وعينة الاراسة: تكون مجتمع الدراسة من أعضاء اللجنة المالية المتكونة من: المدراء العامين، والمداء المدراء

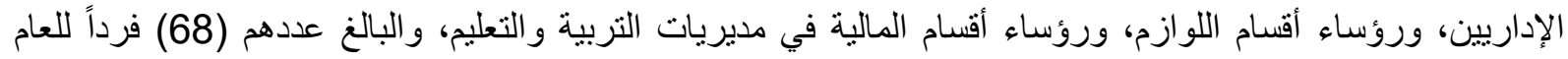

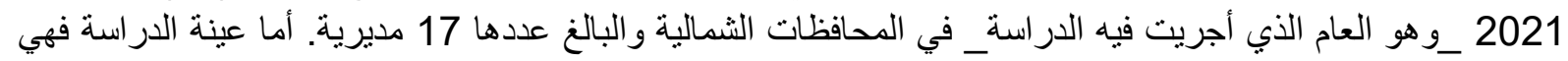

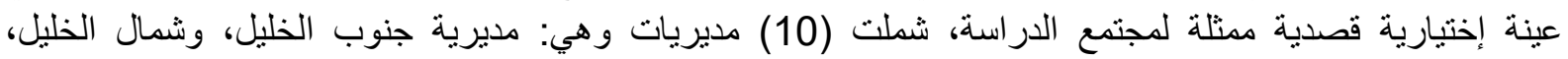

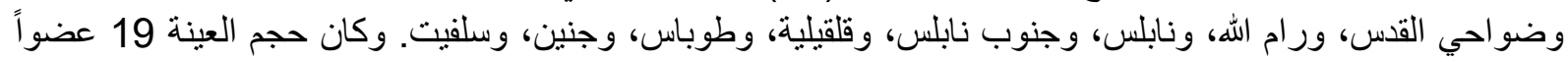

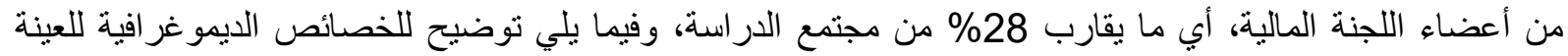

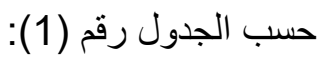

جدول رقم (1): الخصائص الديمو غر افية لعينة الدراسة

\begin{tabular}{|c|c|c|c|}
\hline النسبة المئوية & العدد & عينة الدر اسةة & الخصائص \\
\hline$\% 21.1$ & 4 & مدير عام & المسمى الوظيفي في \\
\hline$\% 15.8$ & 3 & المدير الإداري & المديرية \\
\hline$\% 36.8$ & 7 & رئيس قسم المالية & \\
\hline$\% 26.3$ & 5 & رئيس قسم اللوازم & \\
\hline$\% 5.3$ & 1 & دكتور اه & المؤهل العلمي \\
\hline$\% 26.3$ & 5 & ماجستير & \\
\hline$\% 68.4$ & 13 & بكالوريوس & \\
\hline$\% 31.6$ & 6 & 10_15 سنة & سنوات الخبرة \\
\hline$\% 26.3$ & 5 & 16_20 سنة & \\
\hline
\end{tabular}




\begin{tabular}{|c|c|c|c|}
\hline$\% 42.1$ & 8 & أكثر من 20 سنة & \\
\hline $\begin{array}{l}\% 36.8 \\
\% 63.2\end{array}$ & 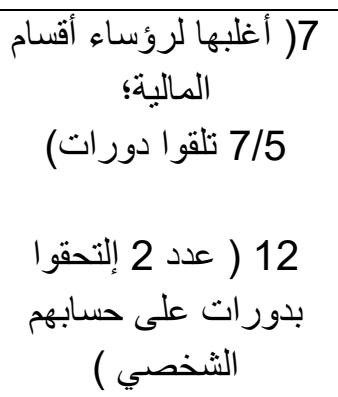 & لايوجد & 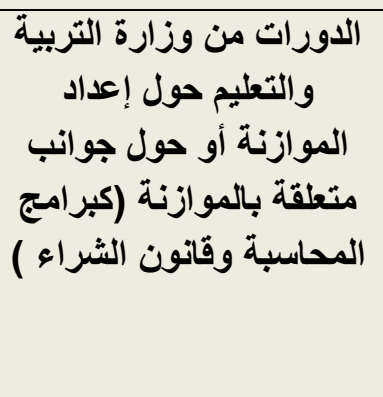 \\
\hline$\% 100$ & 19 & & المجموع \\
\hline
\end{tabular}

أداة الاراسة: من بعد إطلاع الباحثتان على الأدب التربوي الخاص بالموازنة وكفاءة الأداء المالي، وعلى الدراسات

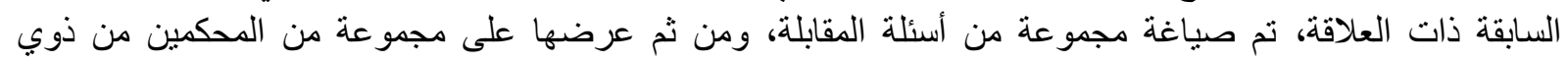

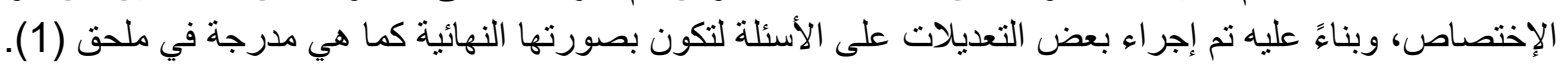

نتائج الدراسة وتفسيرها: فيما يتعلق بسؤال الدراسة الرئيس: "ما دور الموازنة في رفع كفاءة الأداء المالي في مديريات التربية والتعليم في

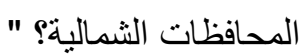

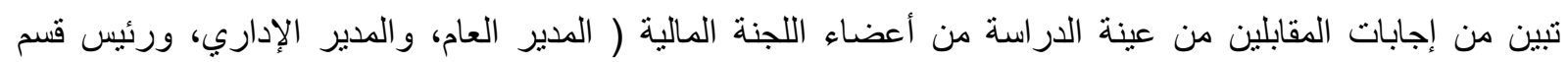

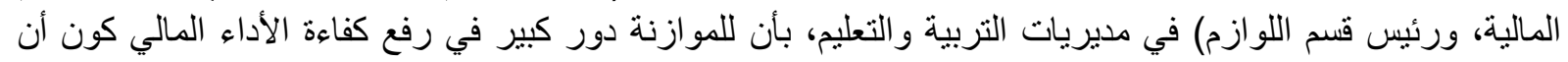

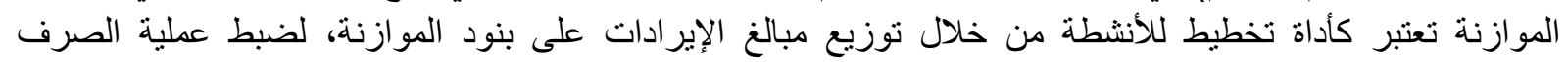

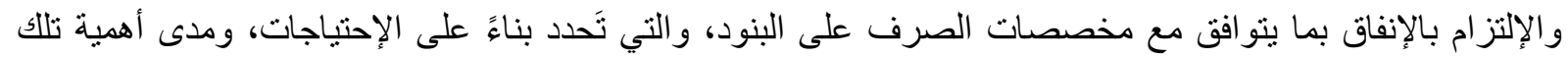

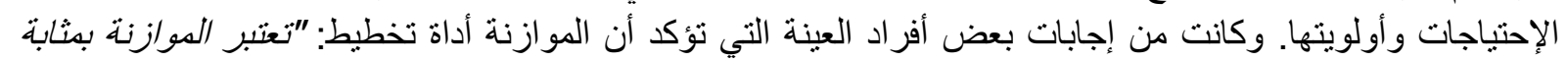

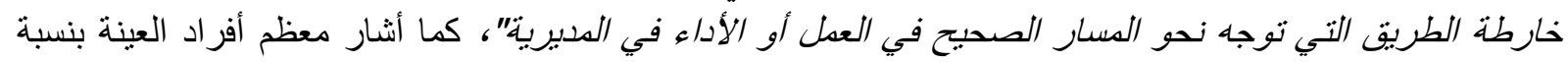

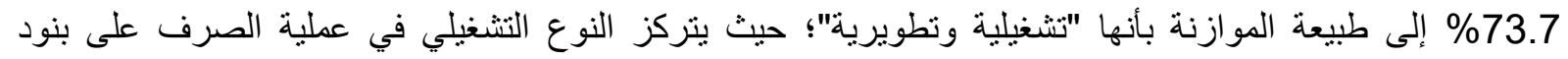

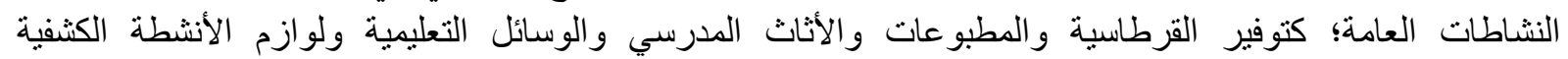

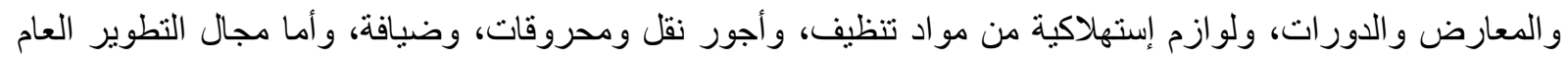

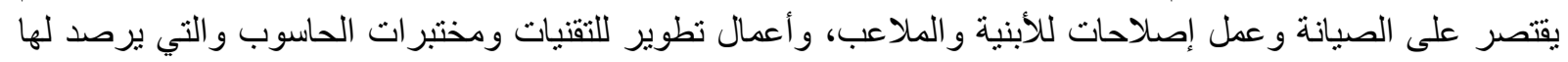

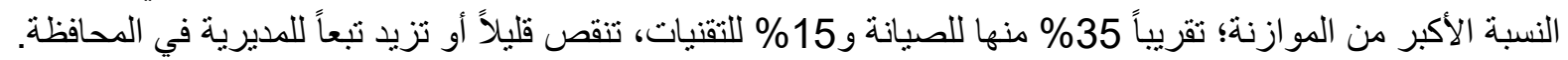

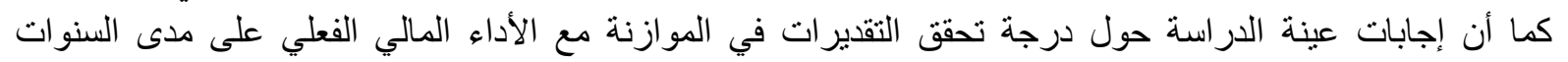

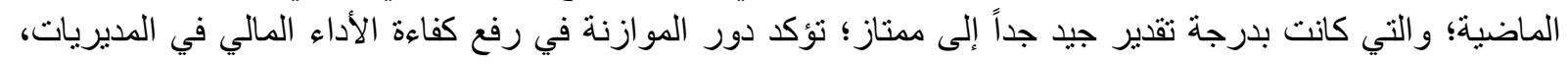

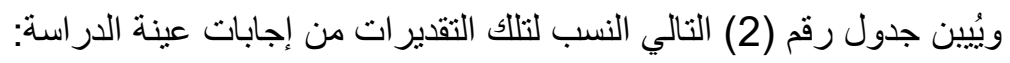
جدول(2): درجة تحقق التقديرات في الموازنة مع الأداء المالي الفعلي على مدى السنوات الماضية

\begin{tabular}{|c|c|c|c|c|c|c|}
\hline المجموع & ضعيف & متوسط & جيد & جيد جداً & ممتاز & 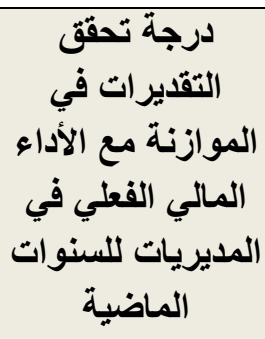 \\
\hline 19 & 1 & 1 & 0 & 9 & 8 & عدد التكرار \\
\hline$\% 100$ & $\% 5.3$ & $\% 5.3$ & $\% 0$ & $\% 47.4$ & $\% 42$ & النسبة المئوية \\
\hline
\end{tabular}


وما يؤكد النتيجة السابقة، إجابة 73.7\% من عينة الدراسة إلى أن الوقت المستغرق في إعداد الموازنة يقابل القيمة

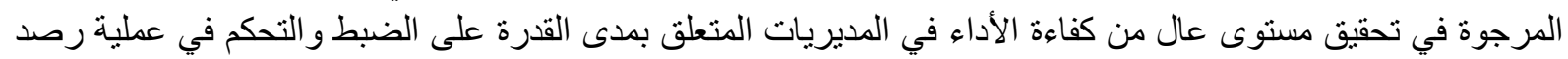

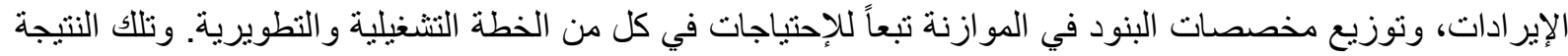

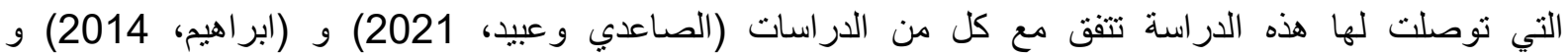

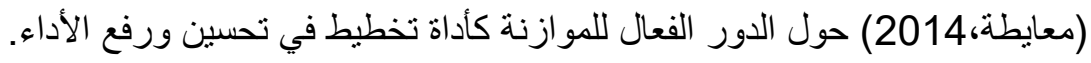

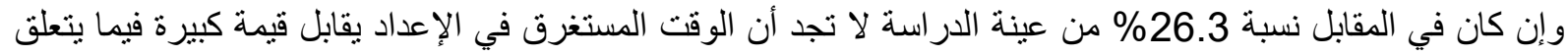

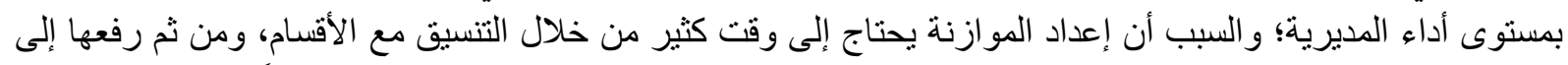

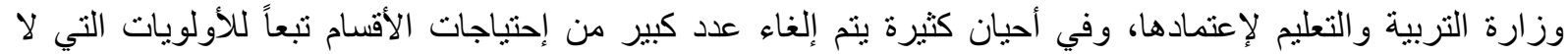

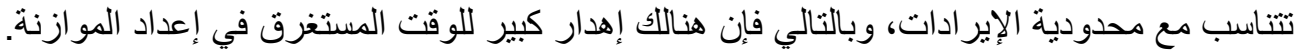

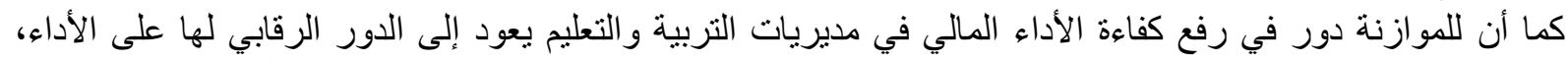

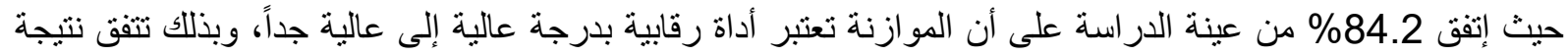

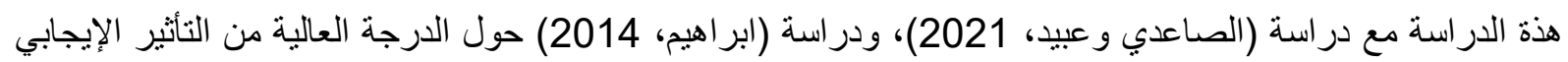

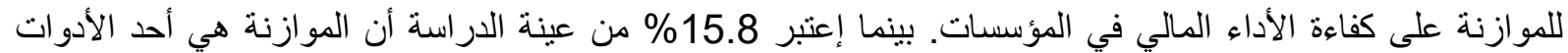

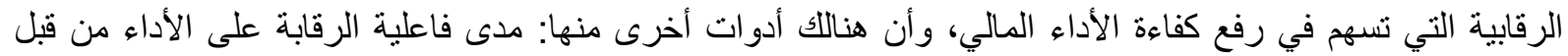

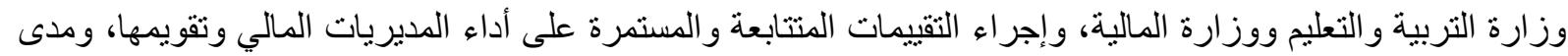

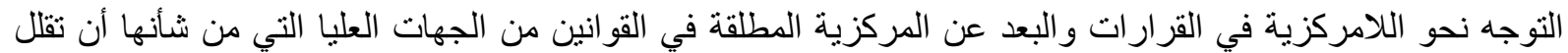

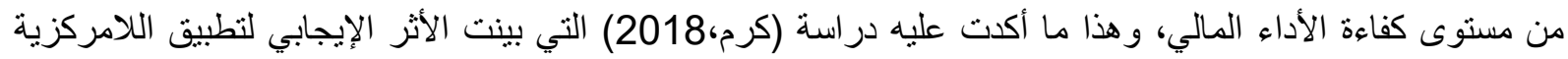
في الموازنات على كفاءة الأداء.

السؤال الأول: ما دور الإعداد للموازنة في رفع كفاءة الأداء المالي في مديريات التربية والتعليج؟ لقد شملت أسئلة المقابلة مجموعة من المحاور الرئيسة المتعلقة بإعداد الموازنة لمحاولة الإجابة على هذا السؤال، وفيما

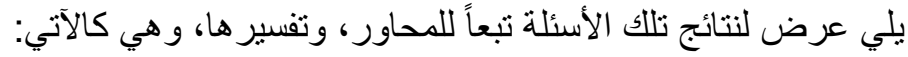

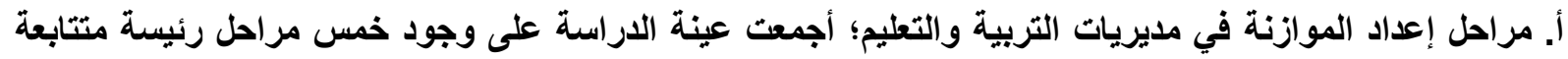

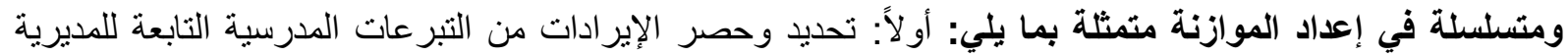

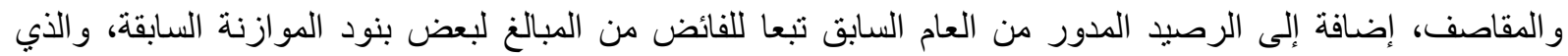

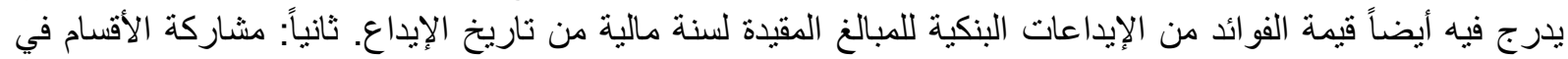

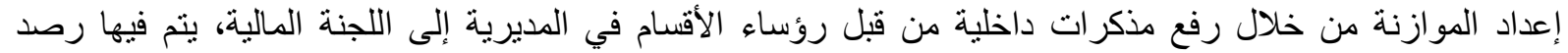

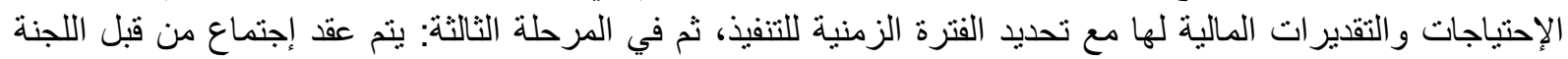

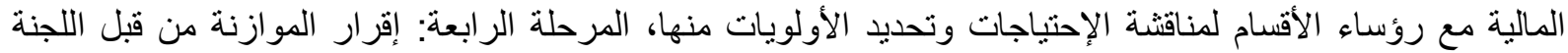

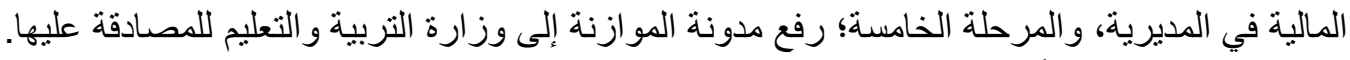

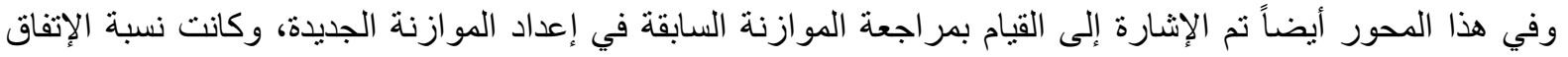

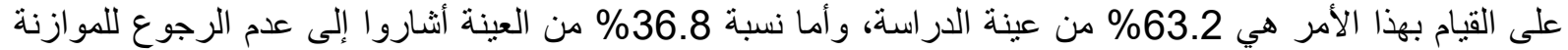

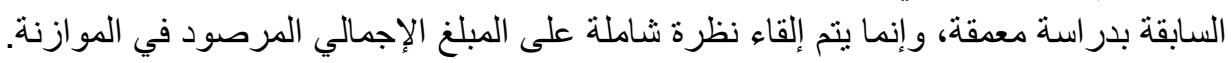

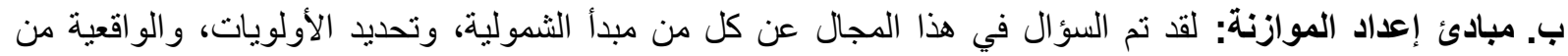

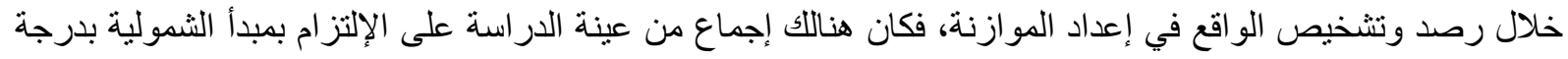

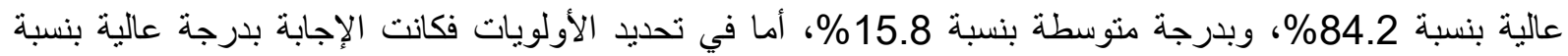

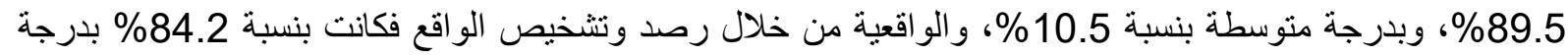

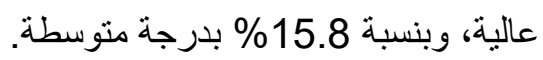

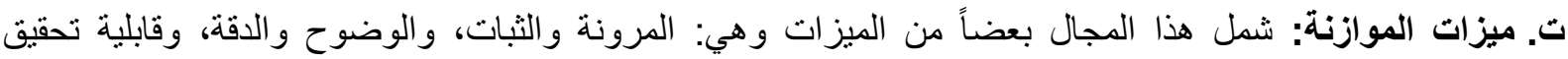

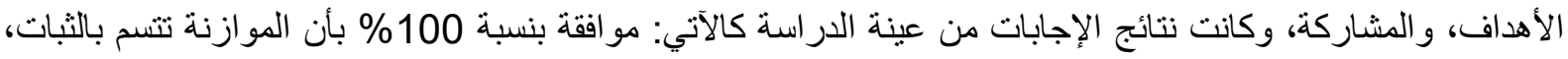
وبنسبة 89.5\% تتسم الموازنة بالمرونة، وبنسبة 89.5\% الإن الموات مازنة تتسم بالوضوح و الدقة، وكانت نسبة الإتفاق بين 
أفر اد العينة على أن الموازنة محققة للأهداف هي 89.5\%، وأما ميزة المشاركة فقد كانت نسبة الإتفاق على وجودها في

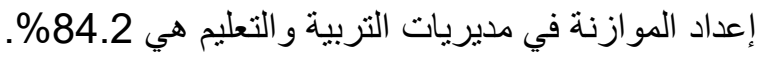

ث. تحديد بنود المساءلات للأداء والإفصاح عنها للأقسام في مديريات التربية والتعليم قبل البدء بالتجهيز لإعداد الموازنة: حيث كان هناك إتفاق ما بين عينة الدراسة بنسبة 63.2\% على القيام بتحديدها مسبقاً، ونسبة 36.8 36.

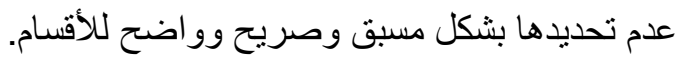

ج. التدريب المستمر على إعداد الموازنة: أجمع معظم أفراد العينة على عدم وجود تدريب باستمرار على إنى إعداد

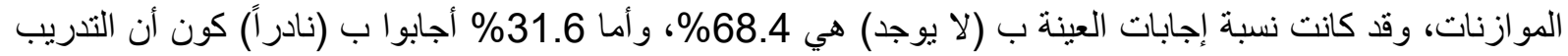

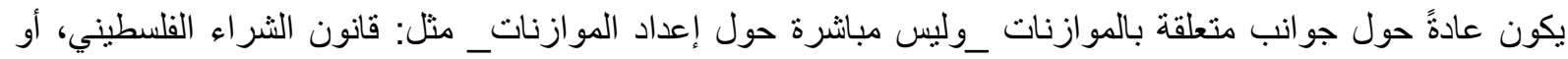

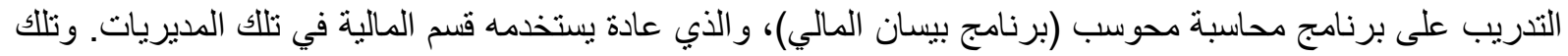

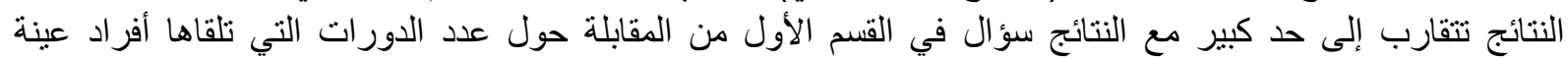

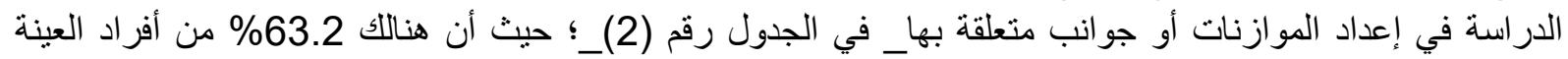

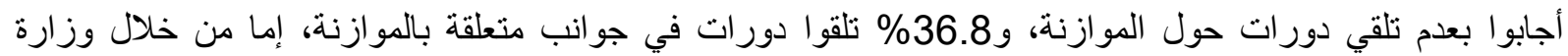

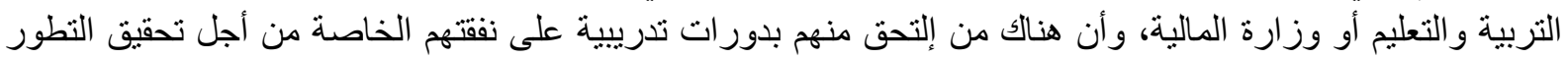
الذاتي لهم في مجال العمل المحاسبي أو المالي. من خلال النتائج السابقة المتعلقة بمجال إعداد الموازنة يتبين ما يلي:

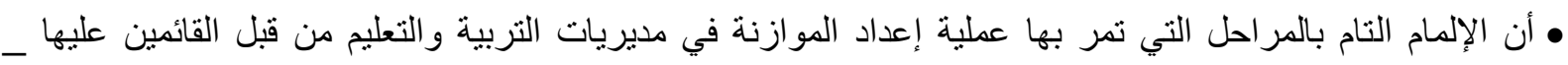

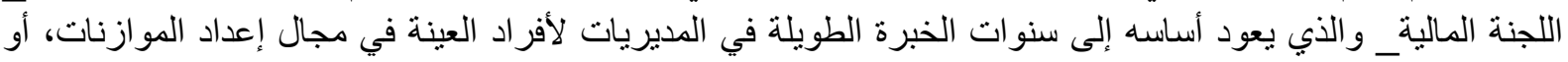

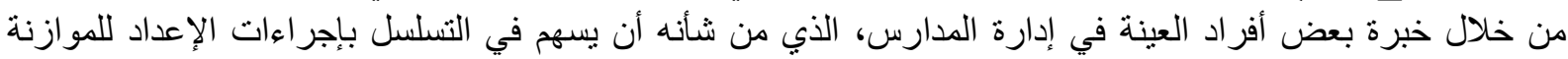

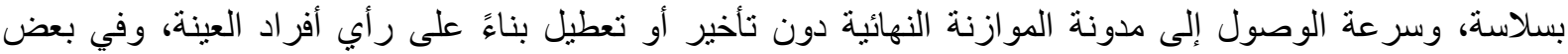

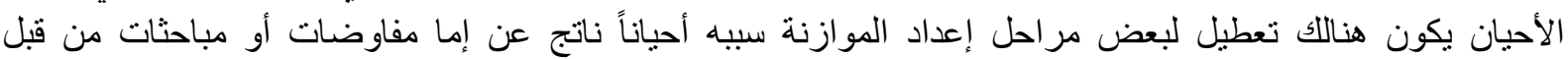

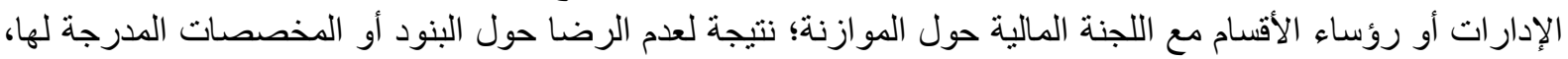

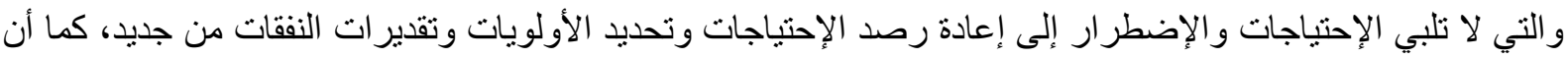

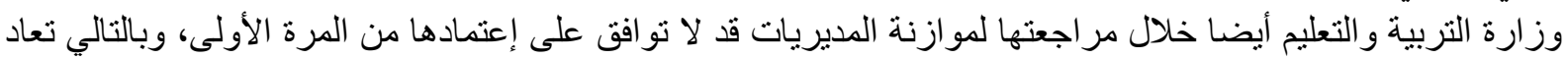

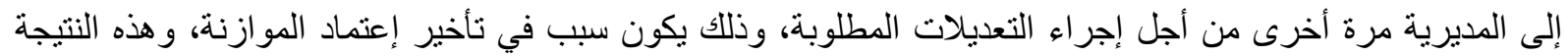
تتفق مع دراسة (Jalali, Mashayekhi, \& Gal, 2019)، التي بينت بأن كثرة التفاوض يؤدي إلى الى إفثال خطة

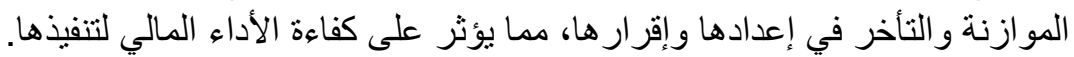

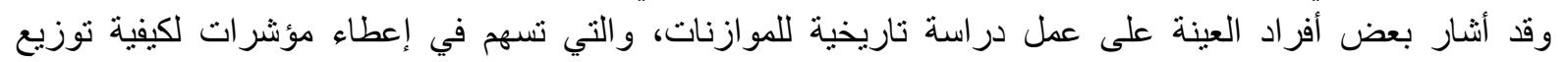

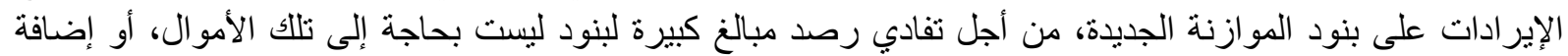

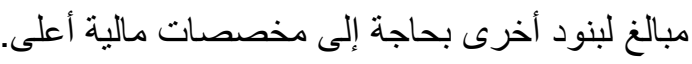

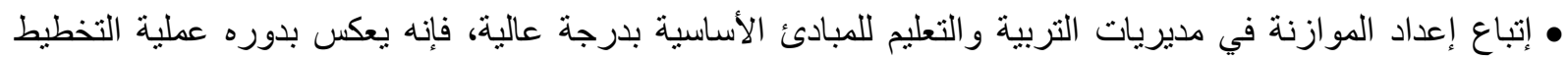

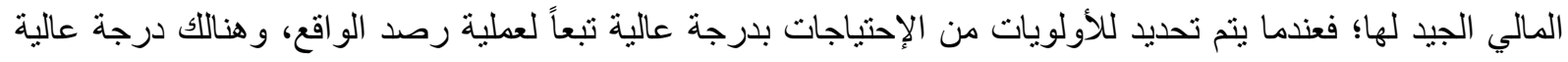

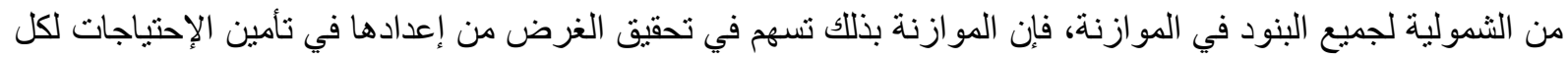

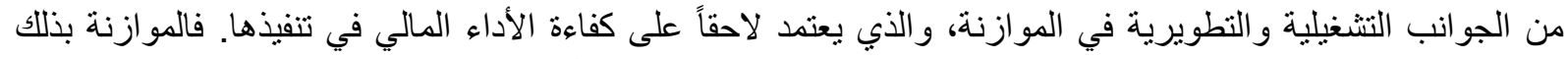

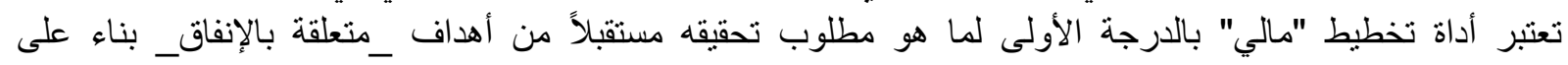

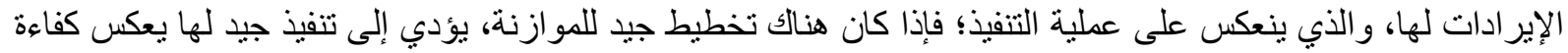

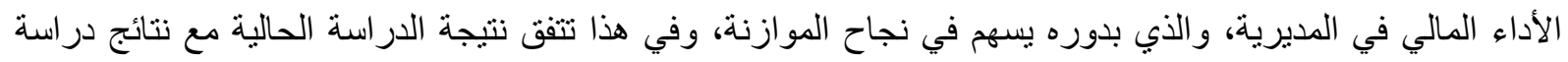

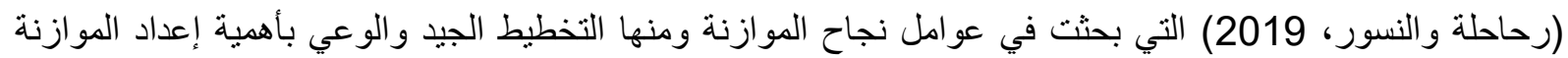
لنجاح تنظيم الأمور المالية في المؤسسات.

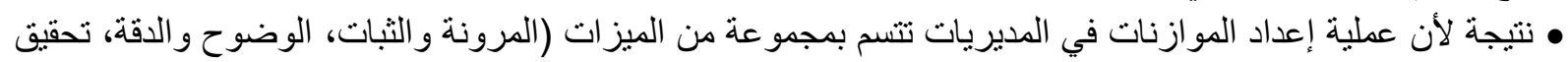

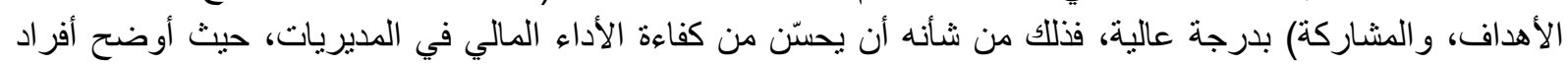

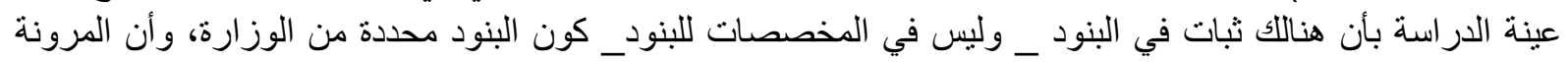

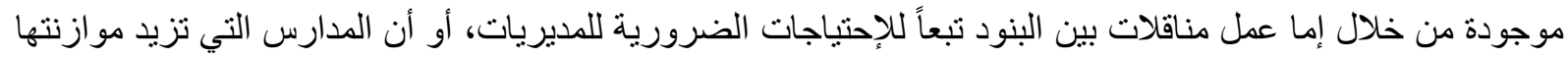


عن( 4000شيقل) يكون من حق المديرية أن تحصل على نسبة 20\% _بناء على تعليمات وزارة التربية و التعليم_ من

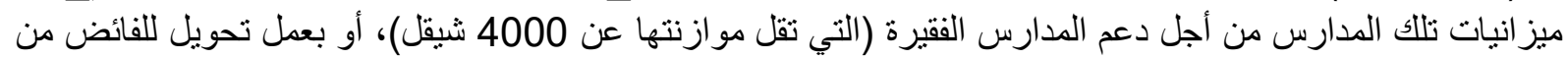

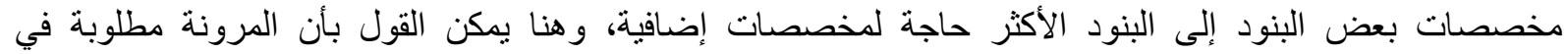

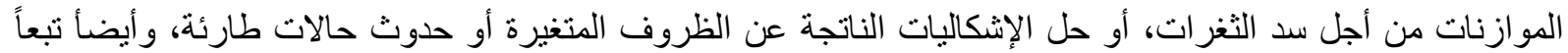

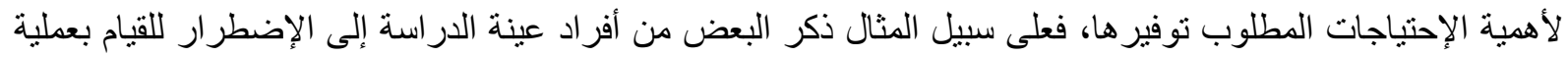

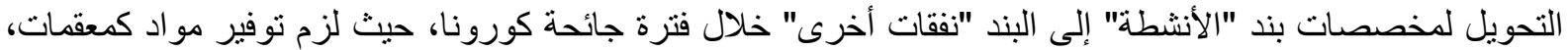

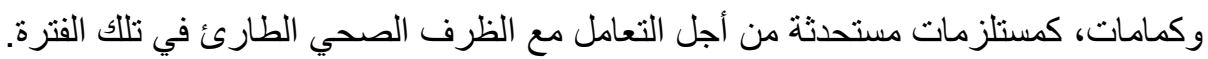

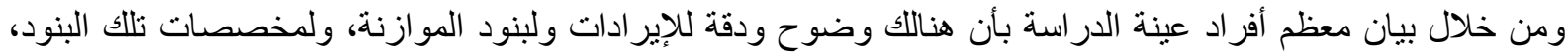

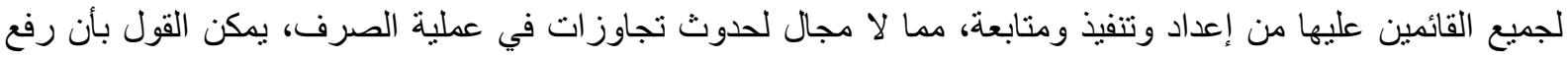

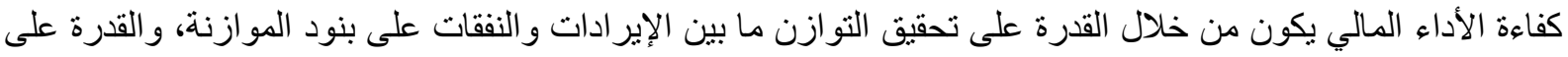

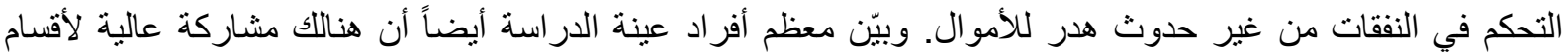

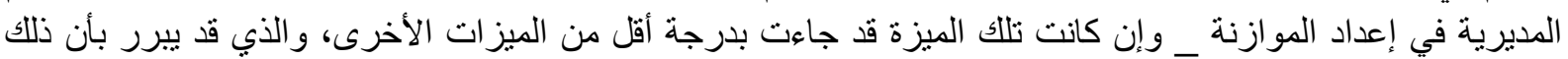

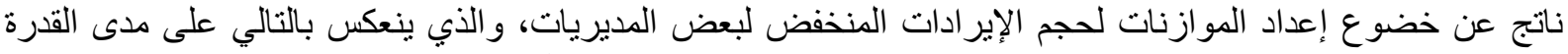

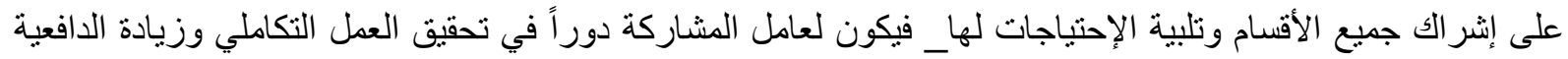

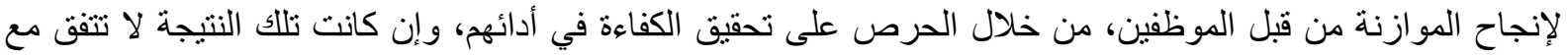

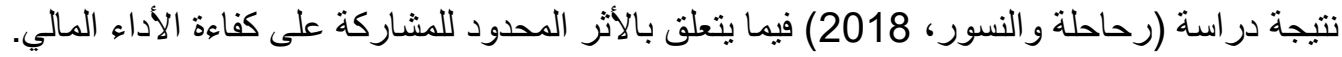

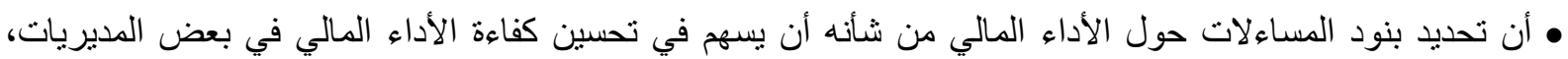

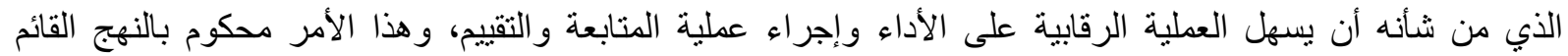

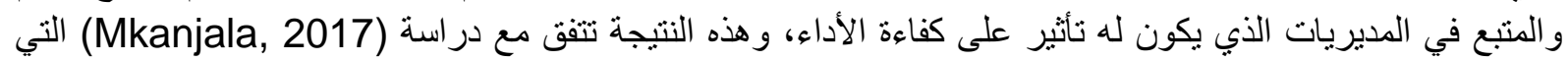

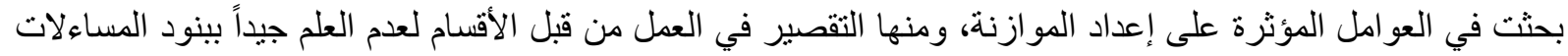

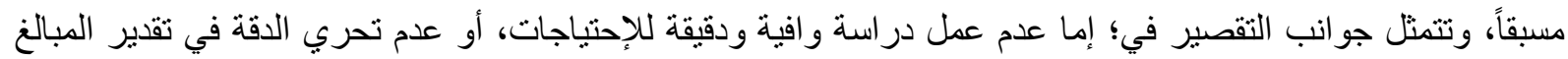

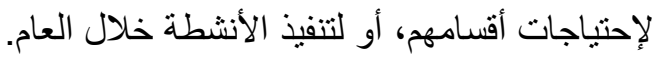

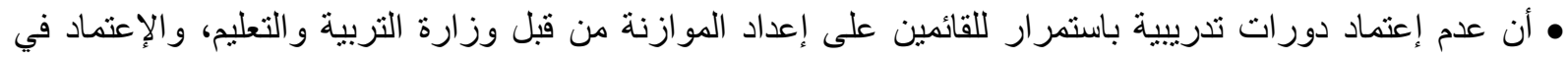

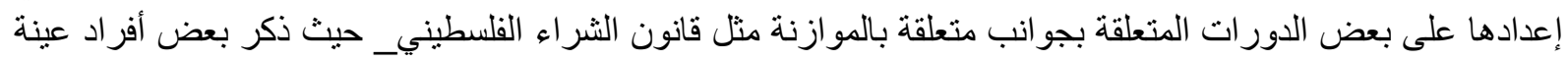

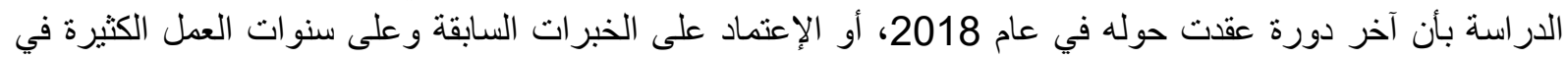

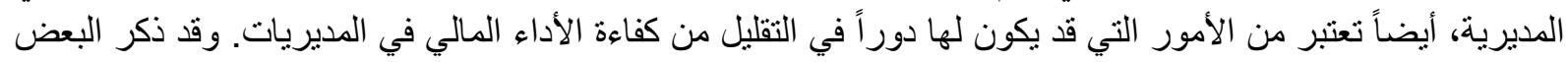

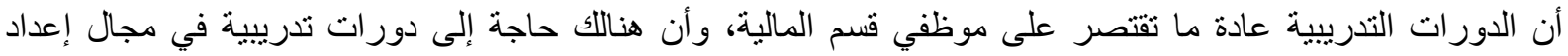

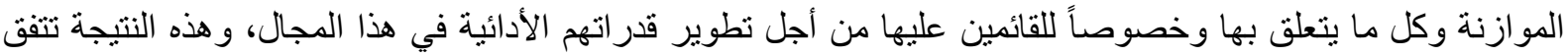

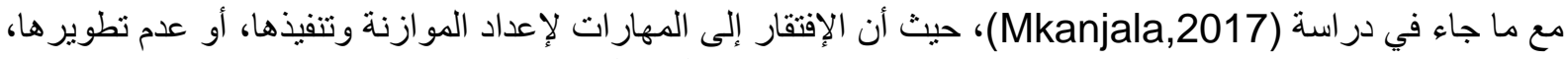

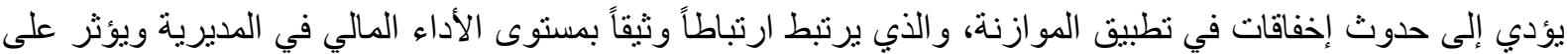

السؤال الثاني: كيف تسهم آليات تطبيق الموازنة ومتابعة تنفيذها في رفع كفاءة الأداء المالي في مديريات التربية والتعليج؟

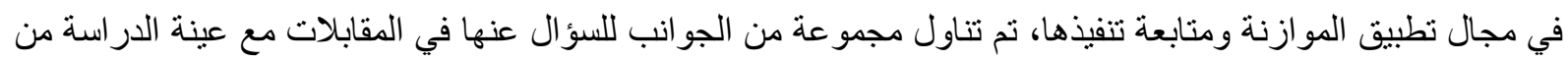

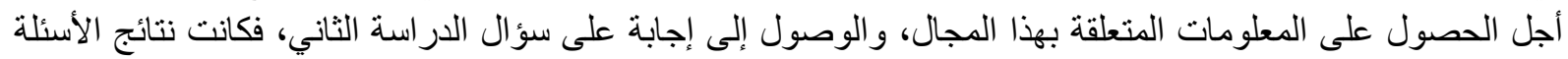

$$
\text { على الجو انب، وتفسير ها، كالآتي: }
$$

أ. آليات تطبيق الموازنة: إتفقت عينة الدراسة جميعها على الآليات التي يتم إتباعها في المديرية في مجال العمل على التى التها تنفيذ الموازنة والتي تمثلت في الآتي: أولا: من بعد المصادقة على الموازنة من وزارة التربية والتية التعليم للمديرية يتم إنشعار

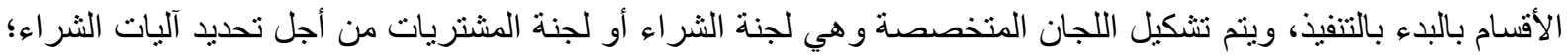

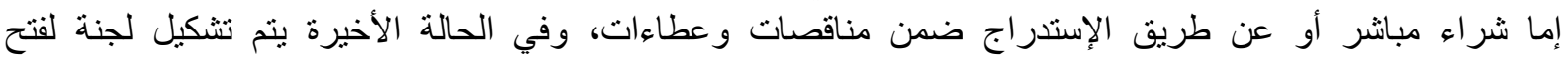

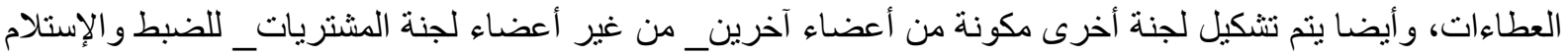

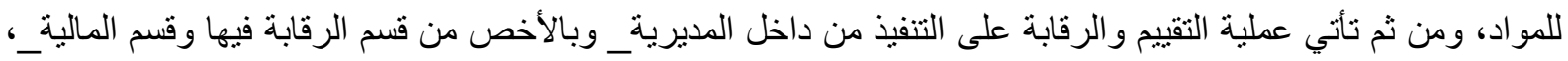


أو من قبل الإدارة العامة للرقابة في وزارة التربية والتعليم، كما أحياناً ينواجد عضو مراقب من الوزارة ضمن اللجان، ولكن وجوده فيها ليس إلز امياً أو دائماً.

ب. متابعة ومراقبة تنفيذ الموازنة: تضمن هذا الجانب مجموعة من آليات المتابعة و الرقابة وهي:

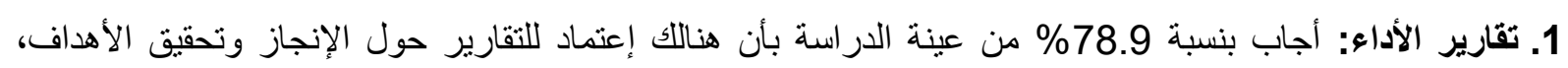

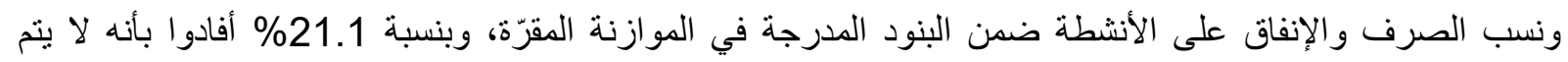

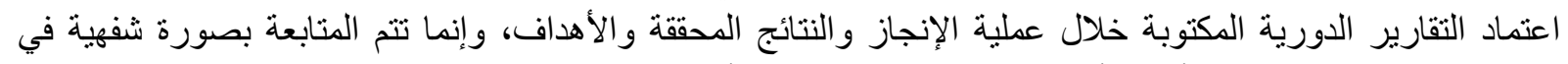

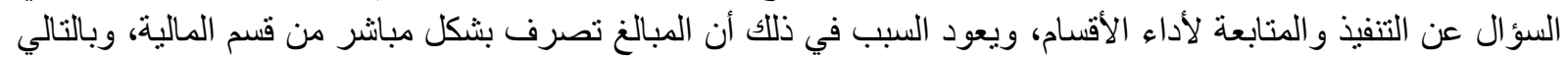

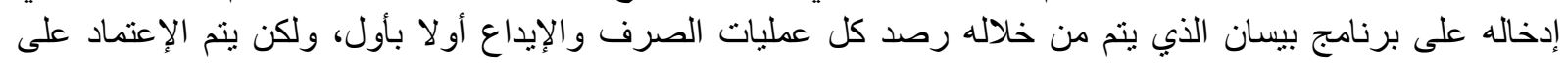

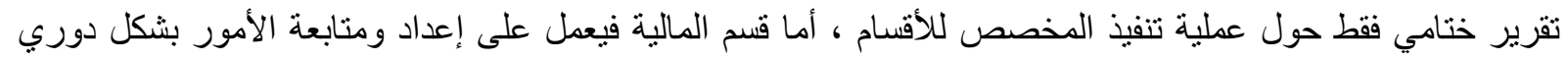

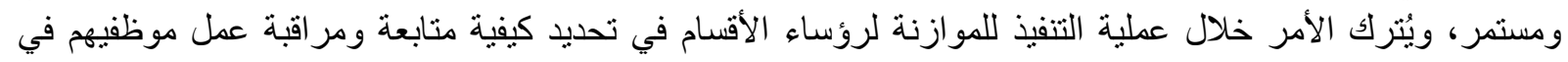
الأمور الفنية.

2. وقت المتابعة: أثنار 68.4\% من عينة الدراسة أن عملية المتابعة لتنفيذ بنود الموازنة تتم بصورة مستمرة خلال

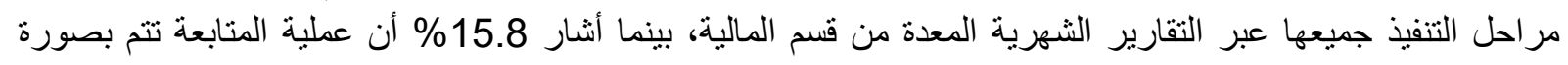

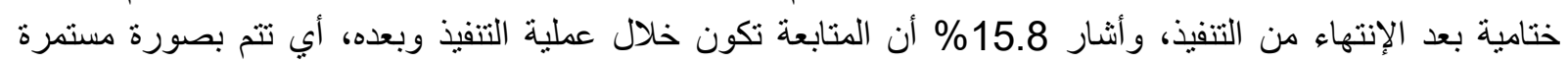
وختامية.

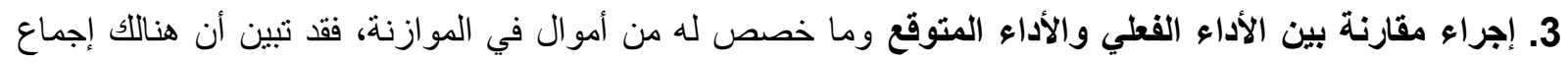

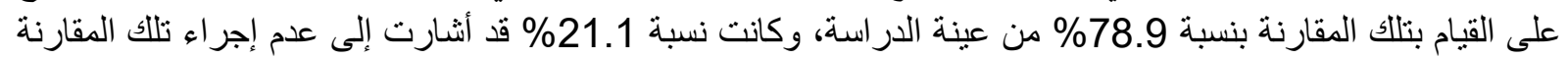

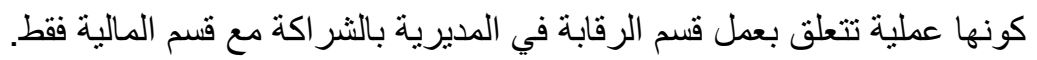

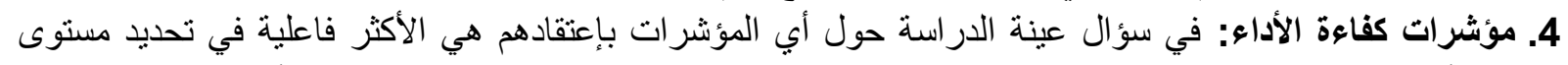

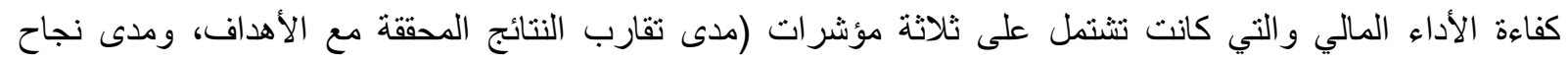

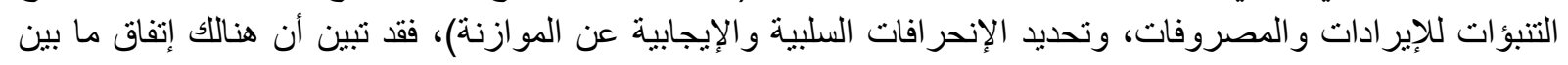

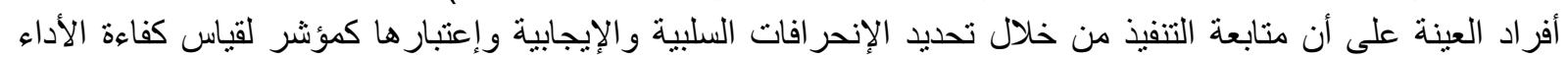

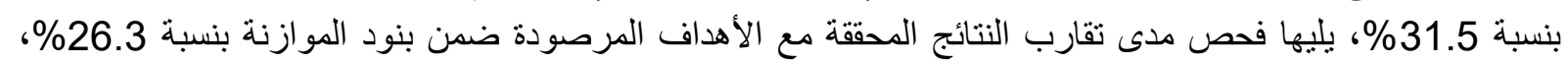

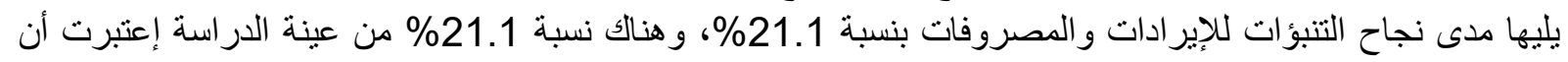

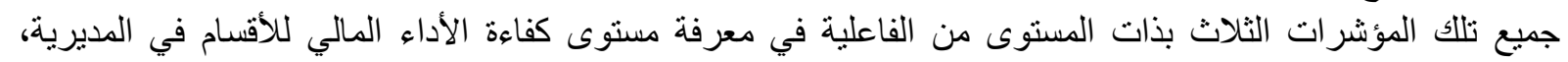

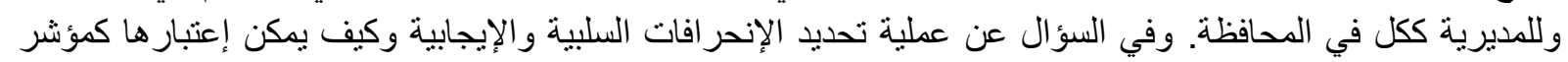

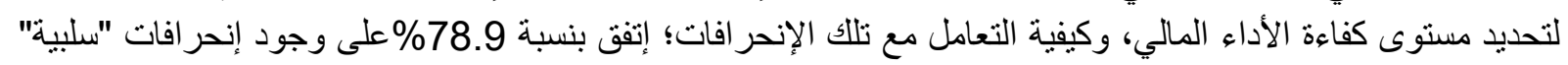

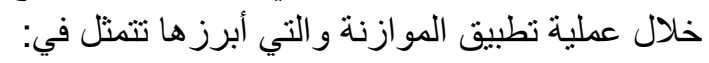

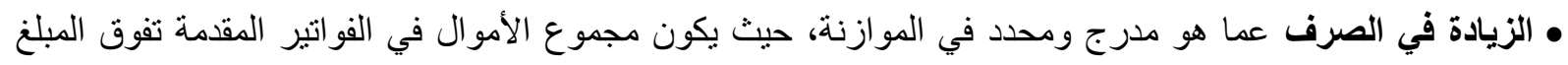

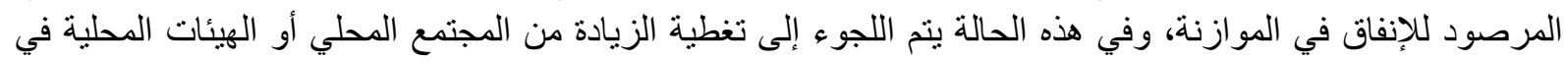

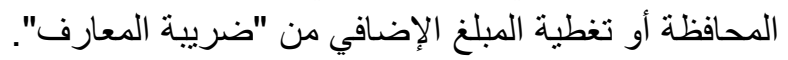

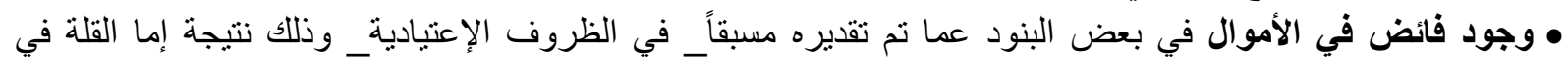

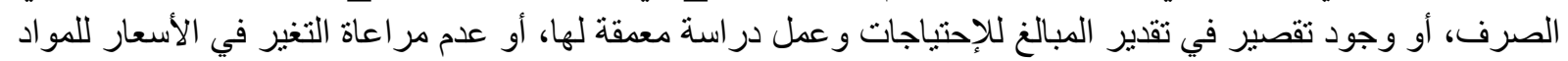

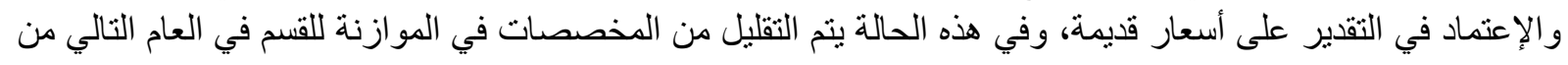

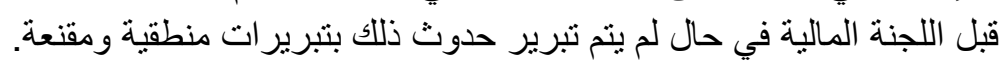

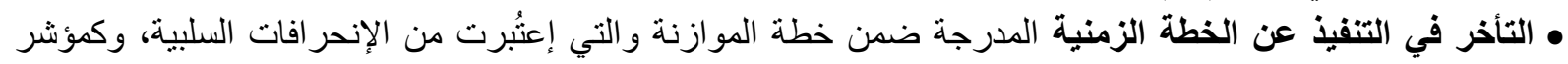

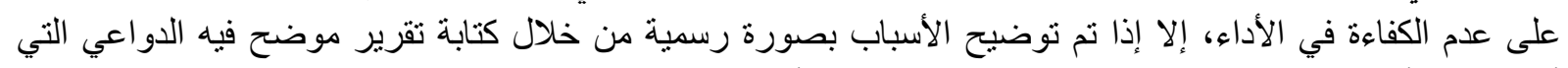

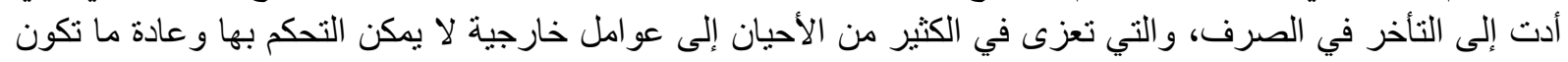

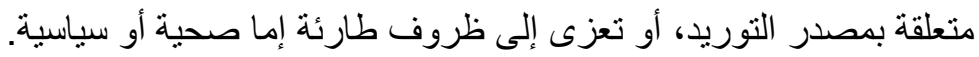

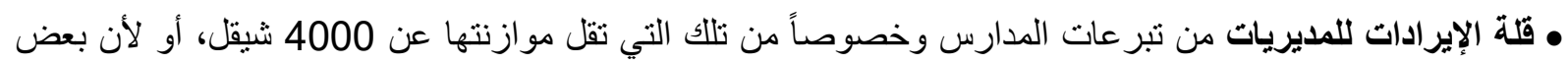
المديريات عدد المدارس التابعة لها قليل على عكس مديريات أخرى، وبالتالي قلة أعداد الطلبة فيها، على سبيل المثال، 
مديرية رام الله تضم 204 مدرسة أما مديرية طوباس تضم 45 مدرسة فقط، مما ينعكس بذلك سلباً على آلية التنفيذ للبنود لعدم كفاية التبر عات للإحتياجات. • عدد المناقلات للأمو ال بين بنود الموازنة التي ينم العمل عليها خلال العاد العام والذي قد يكون ناتج عن إما سوء التقديرات

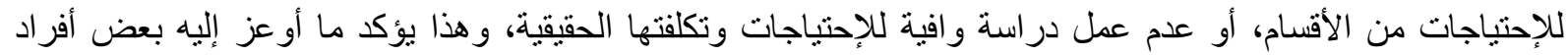
العينة إلى أن حدوث الإنحر افات تكون ناتجة عن وجود تقصير في الأداء من قبل بعض الإن الأقسام فيما يتعلق بتحديد

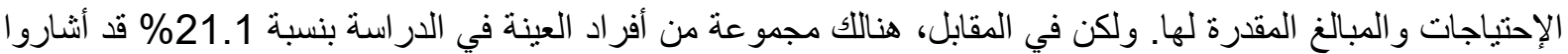

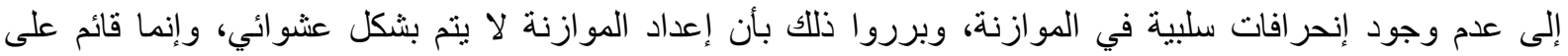

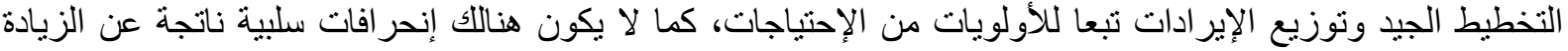

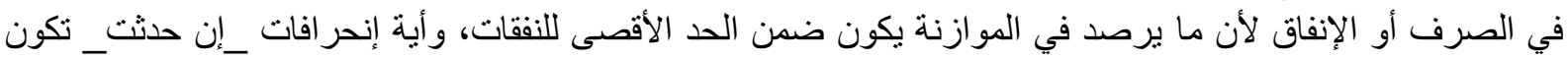

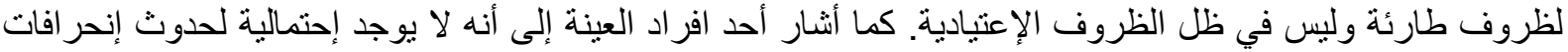

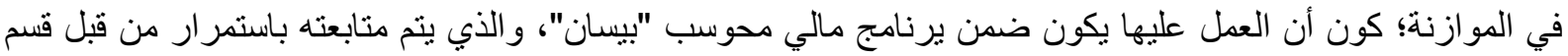

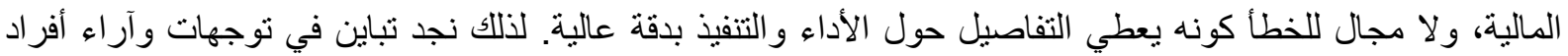

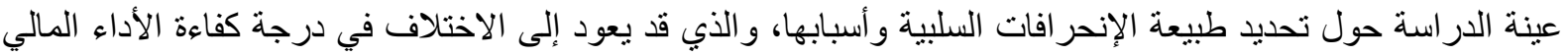

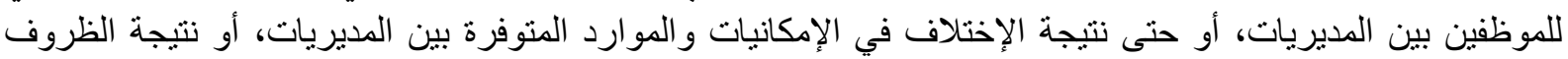

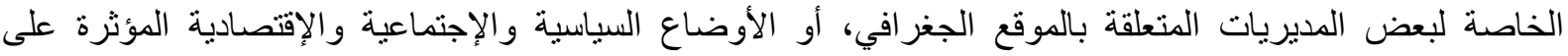

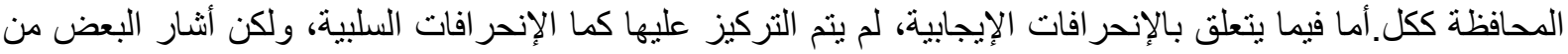

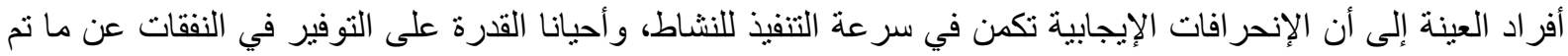

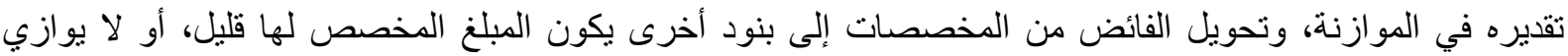
الإنفاق الفعلي لها لتلبية الإحتياجات.

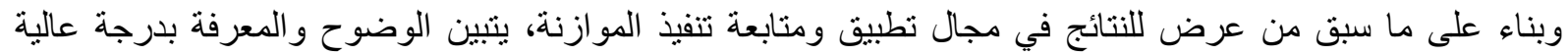

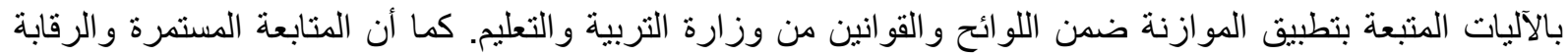

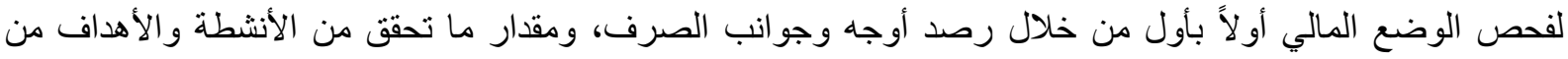

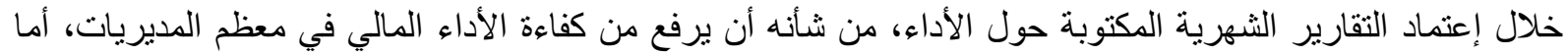

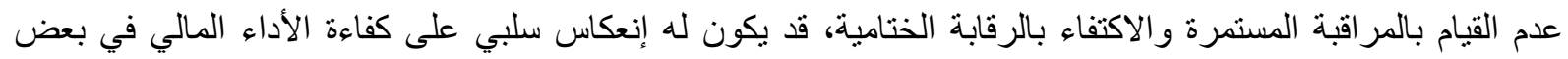

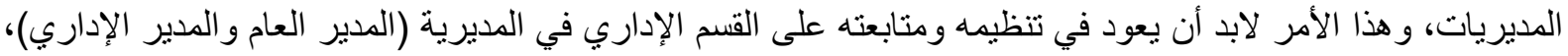

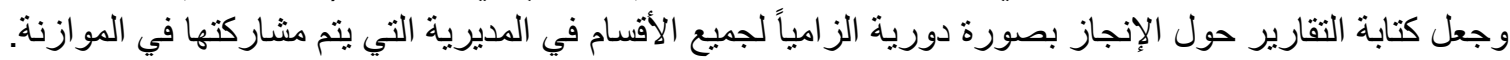

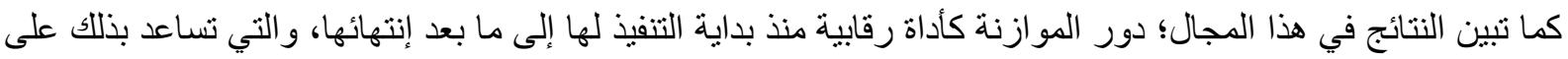

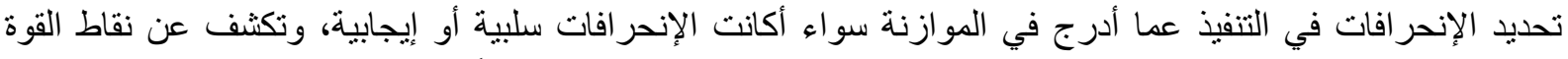

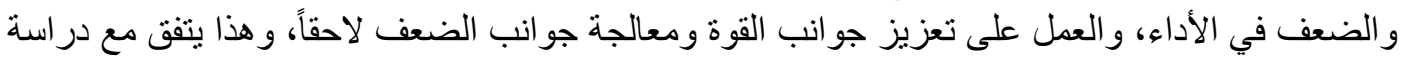
(Kurdieh,2017)

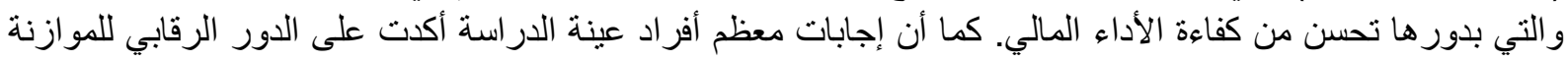
حيث كانت من تللك الإجابات:

"تعتبر الموازنة أداة رقابية على تتفيذ الأنشطة من قبل الأقسام والتي تعكس مستوى أداء المديريات ككل".

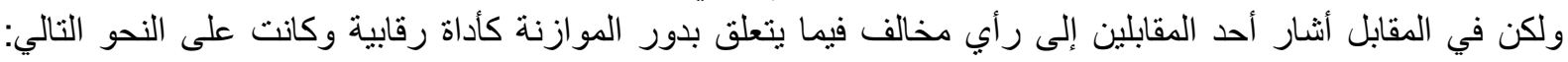

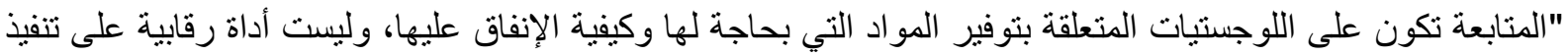

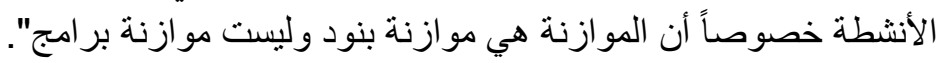

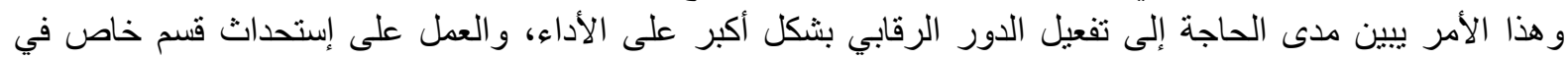

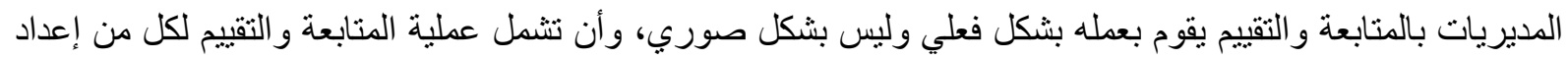

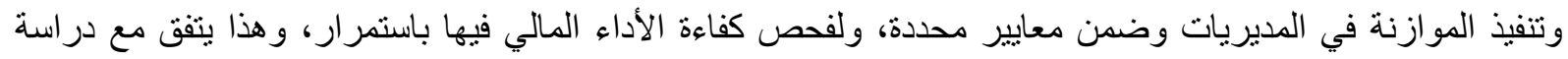
(ابر اهيم،2014) حول أهمية العملية الرقابية للموازنات وفئن وفاعليتها. 


\section{المعيقات في إعداد وتنفيذ الموازنة التي تؤثر بدورها على كفاءة الأداء المالي:}

ذكرت عينة الدراسة مجموعة من المعيقات المتعلقة بكل من إعداد وتنفيذ الموازنة في مديريات التربية و التعليم والتي

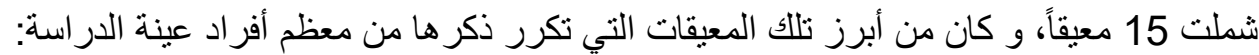
• الظروف الطارئة والظروف البيئية المرتبطة بكل من الأوضاع السياسية والإجتماعية والإقتصادية وكانت نسبة الإجهابة الإنة لهذا العائق 84.2\% من عينة الدراسة.

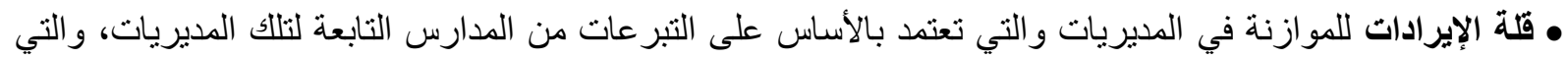

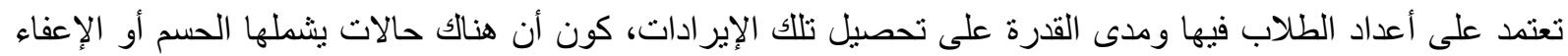

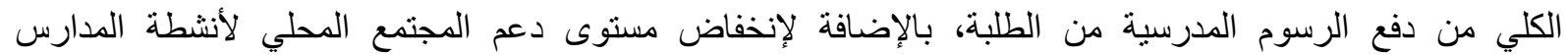

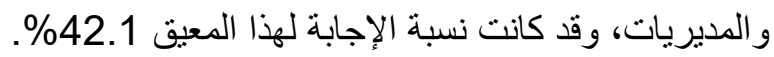

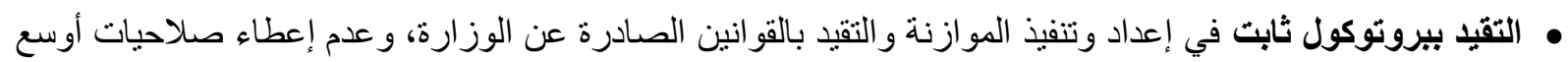

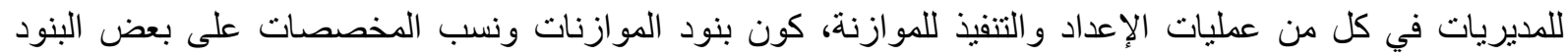

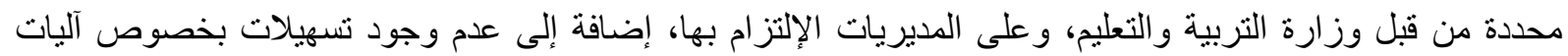

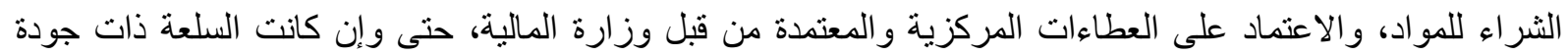

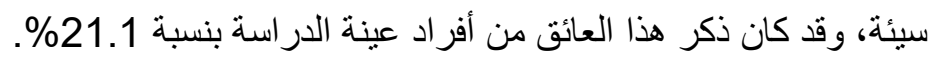

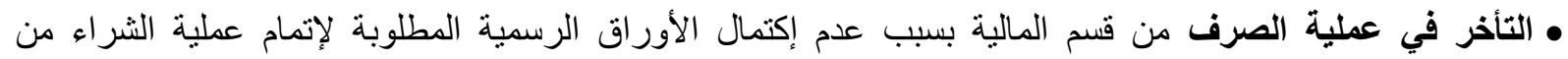

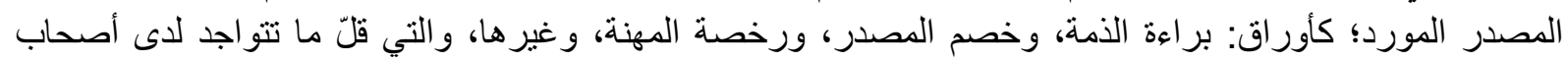

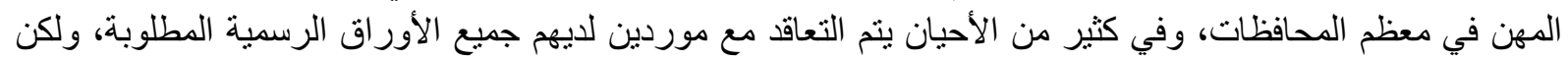

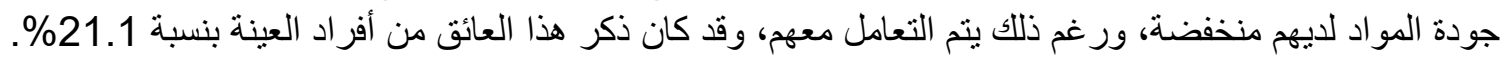

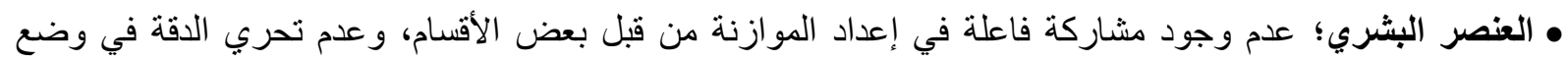

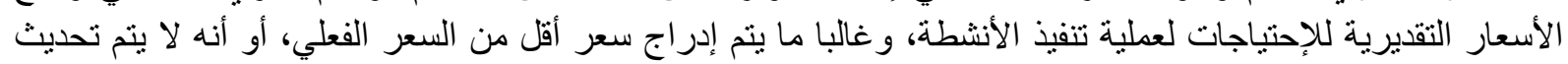

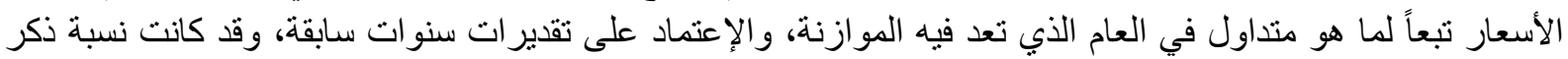
هذا العائق 15.8\%

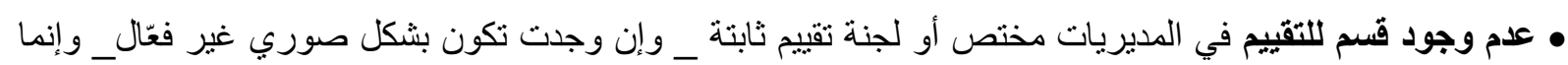

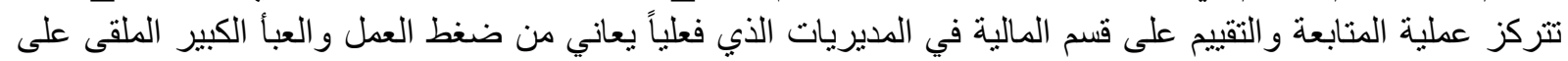

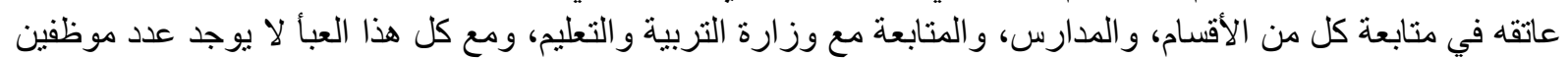

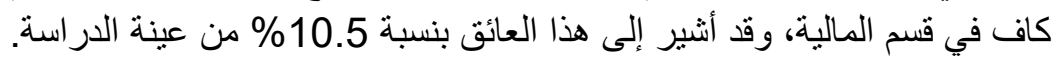

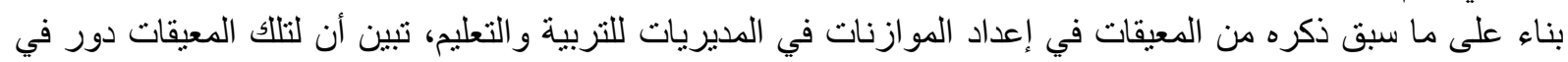

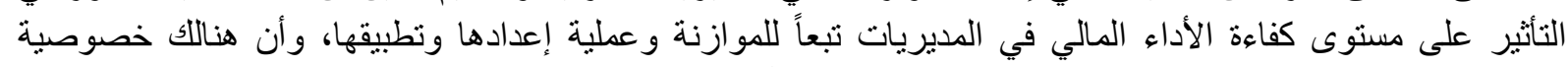

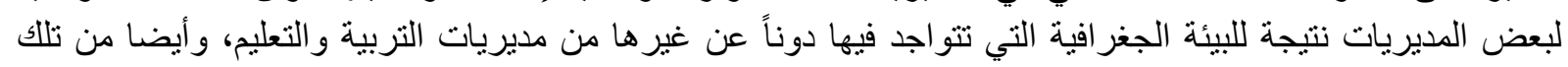

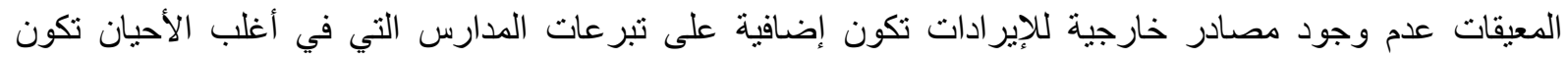

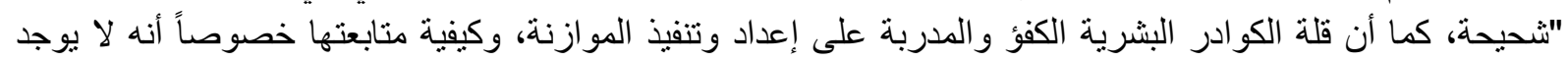

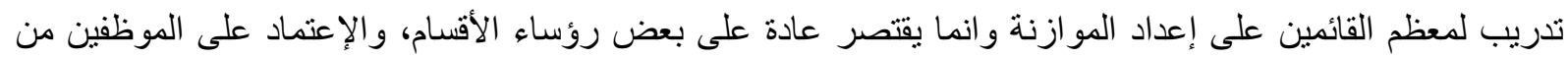

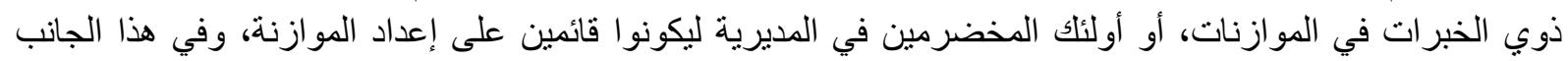

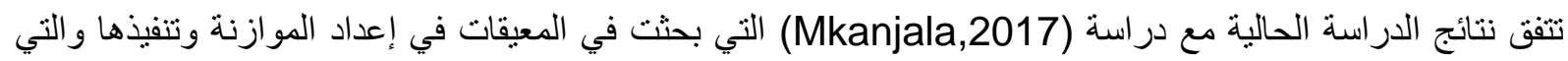

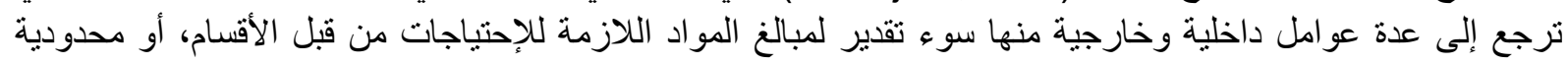

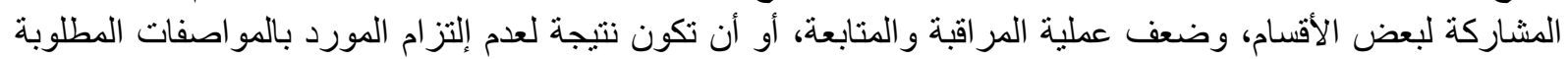

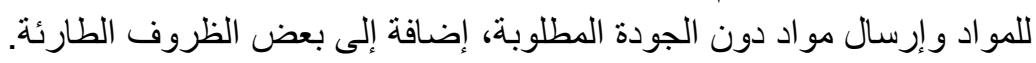

توصيات الاراسة:

تبعا لنتائج الدر اسة وتفسير ها توصي الدر اسة بما يلي: • رفع مستوى مشاركة الأقسام في المديريات في إعداد الموازنة لتكون التهي أكثر فاعلية مما يسهم في زيادة الإنتماء للمديرية و السعي لتحقيق مستوى أعلى من كفاءة الأداء المالي . 
• زيادة صلاحيات مديريات التربية والتعليم في عملية إعداد الموازنة من قبل وزارة التربية والتعليم من أجل تحقيق

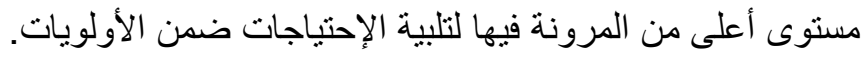
• العمل على إجراء دورات تدرييية حول إعداد الموازنات، وتطبيقها، ومتابعتها من قبل وزارة التربية التربية والتعليم بالتعاون

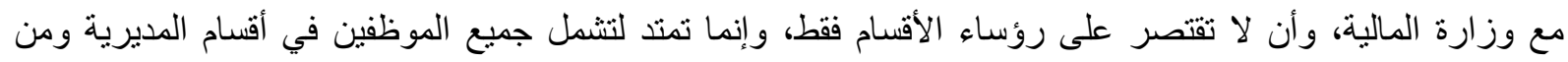

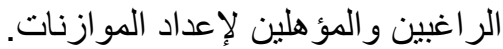
• دراسة المعيقات في إعداد الموازنة وتنفيذها بصورة معدقة من قبل الجهات العهات المسؤولة ومحاولة إيجاد الحلول لتلكي المعيقات من خلال دراسات ميدانية للمديريات جميعها في المحافظات الثنمالية.

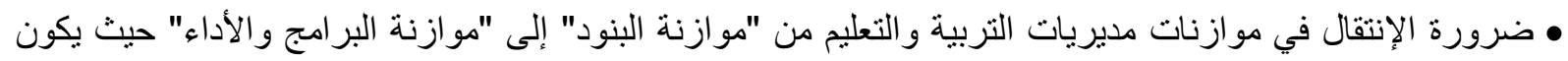

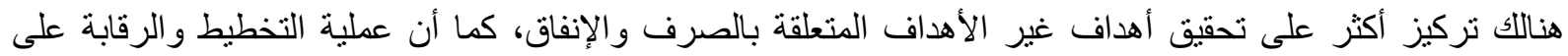
الموازنة تكون أكبر في موازنة البرامج عن موازنة البنود مما تسهم في رفع كفاءة الأداء المالي فيها.

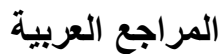

ابر اهيم، رشا. (2014). دور الموازنة التخطيطية أداة تخطيط ورقابة وتحفيز في تقييم الأداء دراسة حالة "جامعة الشرق

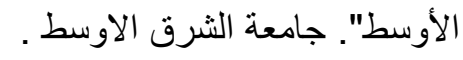

الجنابي، عظيم. (2018). أساس الاستحقاق المحاسبي ودوره في إعداد وتحديد أولويات الموازنة التخطيطية للحكومات المحلية: دراسة تطبيقية في محافظة القادية. المجلة العلمية للدراسات التجارية و البيئية، 9(9)، 602-

خديجة، أو لاد. (2015). أهمية الموازنات التخطيطية في تقويم أداء المؤسسات الاقتصادية: دراسة حالة مجمع سيفيتال.

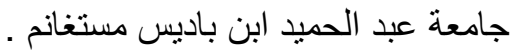

رحاحلة، نادين و النسور، بلال ـ (2019). دور عو امل النجاح للموازنات التخطيطية في تحسين الأداء المالي للمنظمات

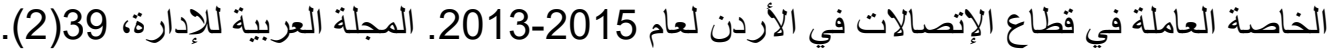

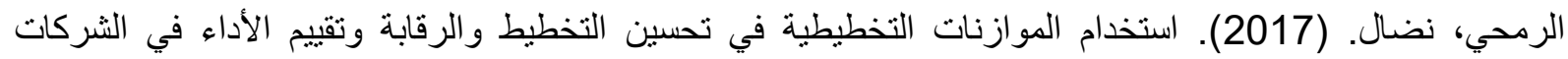

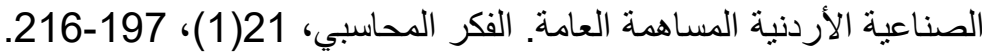

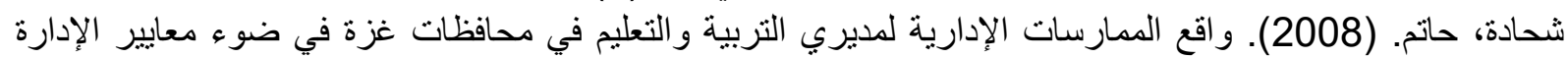

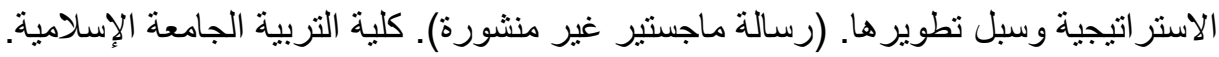

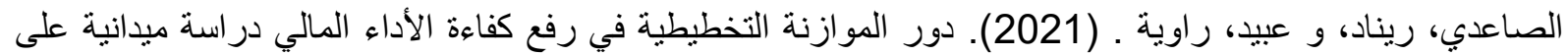

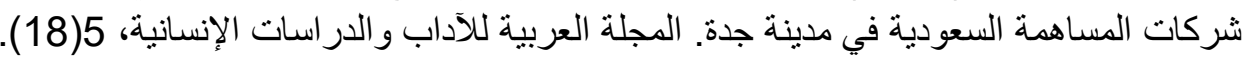

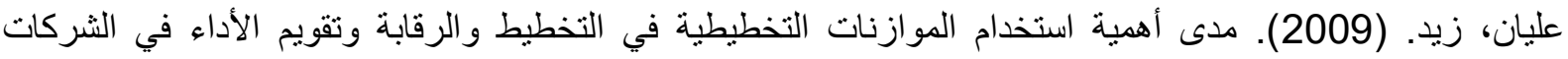

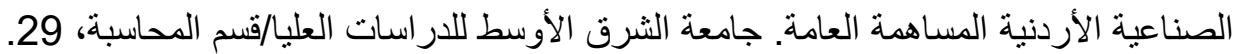

علي، هيثم. (2008). تحليل نفقات جامعة دمشق التخطيطية والفعلية للأعوام 2005-2001: دراسة والألية وصفية تحليلية. جامعة دمشق.

كرم، العاجبة. (2018). أثر تطبيق اللامركزية في الموازنات التخطيطية على كفاءة الأداء المالي بجامعة النيلين. مجلة

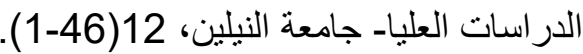

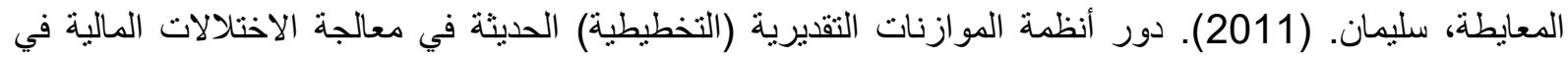

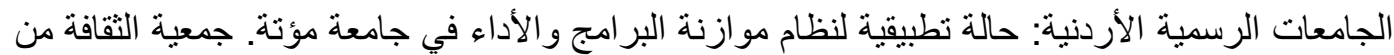

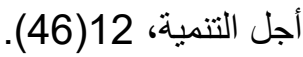
المعايطة، سليمان خالد. (2014). أثر نطبيق نظام موازنة البرامج و الأداء في تحسين الأداء المالي في الجامعات الرسمية

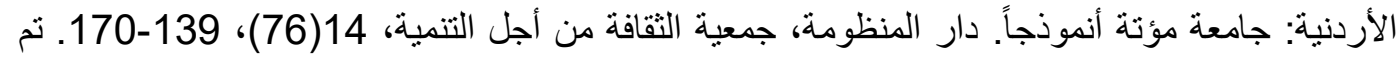

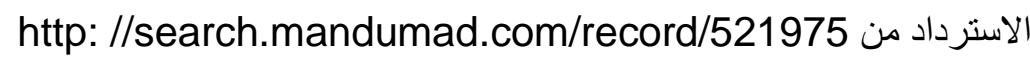

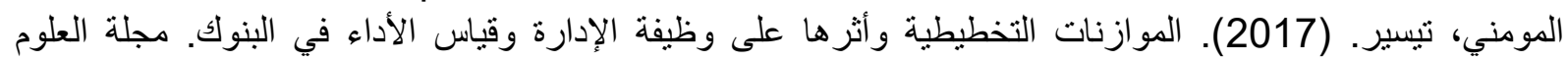
الاقتصادية و الإدارية و القانونية- المجلة العربية للعلوم ونشر الأبحاث، 1) (7). 


$$
\begin{aligned}
& \text { النافعابي، حسين. (2016). مدى أهية استخدام الموازنات التخطيطية في التخطيط و الرقابة وتقييم الأداء في شركات }
\end{aligned}
$$

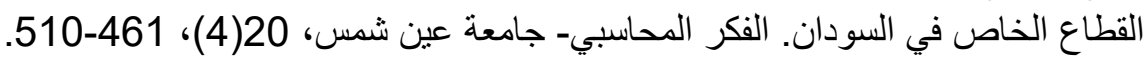

\section{References}

Jalali, F., Mashayekhi , B., \& Gal, G. (2019). Budget preparers' perceptions and performance- based budgeting implementation: The case of Iranian public universities and research institutes. Journal of Public Budgeting, Accounting \& Financial Management, 31(1), 137-156.

Jones, R., \& Pendlebury, M. (2000). Public sector accounting. Pitman Publishing(5).

Kurdieh, R. (2017). Implementation and preparation of the planning budget in civil society organizations in Turkey. "Which concerns Syrian refugees"-A field study. Arab Journal of Science \& Research Publishing, 1(8).

Masakala, C., Omol, E., Wauyo, F., \& Okumu, J. (2017). The role of budgeting in financial performance: A case study of Bugisu Cooperative Union Ltd Mbale, Uganda. American Journal of Finance, 1(5), 31-48.

Merchant, K. (1985). Budgeting and the propensity to create budgetary slack. Accounting, Organizations and Society, 10(2), 201-210. Retrieved from https: //doi.org/10.1016/0361-3682(85)90016-9

Mkanjala, M. (2017). Factors affecting budget preparation: A case study of USIUAfrica. United States International University, Africa.

Nouri, H., \& Parker, R. J. (1998). The relationship between budget participation and job performance: The roles of budget adequacy and organizational commitment. Accounting, Organization and Society, 23(5-6), 467-483. Retrieved from https: //econpapers.repec.org/article/eeeaosoci/v-3a23

Rogulenko, T., Ponomareva, S., Badiaco, A., Mironenko, V., \& Zelenov, V. (2016). Budgeting-Based Organization of Internal Control. International Journal of Enviromental \& Science Education, 11(11).

Ruppel, W. (2015). The importance of budgets to goverments. Wiley GAAP for Governments 2015: Interpretation and Applicatio.

Siregar, B., \& Susanti, L. (2019). Determinants of budget forecast errors and their impacts on budget effectiveness: Evidence from Indonesia. Journal of Economics, Business \& Accountancy Ventura, 21(3), 391-399.

Tafa, D., \& Bessie, S. (2016). Intrinsic factors affecting budget utilization in Ethiopian public universities . Journal of Economics and Sustainable Development , 2222-2855. 